\title{
PICKING UP (ON) FRAGMENTS
}

\author{
Phil Ellis \\ Plymouth University \\ Room 111, Scott Building \\ Plymouth \\ Devon \\ United Kigdom \\ PL4 8AA \\ p.ellis@plymouth.ac.uk
}

Reenactment is distinctive in that it invites transformation through memory, theory, and history to generate unique and resonating results. ${ }^{1}$

\begin{abstract}
This article discusses the implications for archival and media archaeological research and reenactment artwork relating to a recent arts practice project: Reenacttv: 30 lines / 60 seconds. It proposes that archival material is unstable but has traces and fragments that are full of creative potential to re-think and re-examine past media historical events through a media archaeological approach to reenactment. The article contains images and links to videos from the final reenactment artworks as well as from rehearsals in Vienna and Bradford.
\end{abstract}

Keywords: re-enactment, media archaeology, archive, participation, trace, history

This project is, and was from the outset, a speculative exploration with a central theme of what could be learnt from the relationship between historical television (both technical and the aesthetics of the practice) and the technical and aesthetic possibilities of a 'new' television practice. The starting point was quite simple: a friend peering at the small screen of a smart phone while pixels danced and distorted most unlike the same football match that was playing in full HD on the 'TV' set in the corner of the room. But the friend didn't seem to mind - he was more interested in the fact that, despite the poor Wi-Fi connection, he had television in his pocket, even if it did look like the unstable images from early television that reside somewhere in the memory - themselves re-mediated and emulated through later technology.

The project is not concerned with 'one-to-many' broadcast television (as in the television set described in the above anecdote) that early television grew into, but is interested in the aspects of a new television that concerns the move from viewer to participant, not only as active feedback but also through direct creative practice. The research for the project, and subsequent practice described later, had two major themes. Firstly, the project interrogated early television experiments (specifically focusing on John Logie Baird's broadcast of The Man with the Flower in his Mouth), which lay out the revisiting of history and key historical media events as a driver for a research project. The second theme is reenactment practice and its artistic use. 


\section{Media Archaeology}

When I began my research into early television, I had not yet defined the focus of the practice (and how it might be formed), but there was always the intention that the archival research would be 'active' and creative. In terms of specific focus, I researched John Logie Baird, partly because of the recognition that his interests were beyond just the technical invention of television in the United Kingdom for which he is mostly known-though, as Patrice Flichy points out, Baird developed a 'frame of use' with his mechanical system but the 'frame of functioning' was soon superseded by EMI, Marconi's electronic system. ${ }^{2}$ Baird was also keen to experiment with the 'use' of the invention, leaving Baird's perception as one which "runs the risk of leaving important statements, objects, and networks of power in neglected margins." 3 Baird's intent might be characterised by his positioning between what Knut Hickethier terms as the second period (1890-1910) of television: 'technical imagination and amateur experimentation' and the third period (1910-1933) of 'technological developments at an industrial level.' In contextualizing programming developments across Europe and the USA, Hickethier focuses on the "medial similarity between radio and television," 5 so it is not a coincidence that the involvement of the industrial broadcasting giants shaped, and perhaps limited the possibilities as the second period turned into the third, leaving material evidence and clues to alternative futures.

This research therefore intended to "to dig out secret paths in history, which might help us to find our way into the

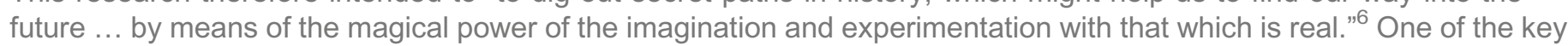
contemporary media archaeologists, Jussi Parikka, suggests that beyond or in tandem with marginalised historical media, the power of the imagination that was present in 'imagined' historical media (especially in this transition period between the imagined and technically (im)possible) can be applied to a methodology of the discipline "that displace[s] our normal ways of approaching what is media and explore media as intensities, sensations, the unthought of. In short: media beyond the representational." 7 This is extremely pertinent when applied to the birth of television. Hickethier proposes that humans have a desire "to explore phenomena in their structure and nature ... to control them and make them usable" and to "quickly get information about an event, if possible in the moment when it is happening." Therefore, there is an inherent fantasy/imaginary in humans ahead of the technological invention of the medium. Simone Natale and Gabriele Balbi further suggest that "approaches to the imaginary in media history have not yet considered media from a perspective which is dynamic in time. Media continuously change in nature, uses, technology, audiences, and significance; the result is that in each moment in a medium's evolution we find different fantasies." Natale and Balbi separate a medium's life cycle into three periods: media prediction/prophecy which reveals "contemporary thinking about communication and its possibilities;" new media (at the point of its introduction) that allow for "a reservoir of possible interpretations to be experimented with and applied," and old or potentially obsolete media that can be seen to be "helping communities to rethink the role of old media and to stimulate their change." 10

Television (past, present and future) has the potential to be simultaneously approached from each of these positions within a media archaeological methodology for artistic practice. Such work goes beyond a literal and linear historical approach (problematic in itself), to "engage sensations in us in ways that are not familiar," as an act of Brechtian alienation in order to open spaces to "invoke concrete alternative histories ... fabricate new machinic apparatuses in an experimental fashion."11

2 Patrice Flichy, Understanding Technological Innovation: A Socio-Technical Approach, Edward Elgar Publishing, 2007, p. 123.

3 Jussi Parikka \& Garnet Hertz, 'Interview: Archaeologies of Media Art: Jussi Parikka in conversation with Garnet Hertz,' CTheory, 2010

4 Knut Hickethier, 'Early TV: Imagining and Realising Television' in A European Television History, Jonathan Bignell \& Andreas Fickers, eds., Blackwell Publishing, 2008, p. 55.

5 lbid., p. 56.

6 Siegfried Zielinski, 'Media Archaeology,' CTheory, 1996.

7 Jussi Parikka \& Garnet Hertz, 'Interview: Archaeologies of Media Art: Jussi Parikka in conversation with Garnet Hertz,' CTheory, 2010.

8 Knut Hickethier, 'Early TV: Imagining and Realising Television' in A European Television History, Jonathan Bignell \& Andreas Fickers, eds.,

Blackwell Publishing, 2008, p. 57.

9 Simone Natale and Gabriele Balbi, 'Media and the Imaginary in History,' Media History, 20:2, 2014, p. 204.

10 lbid., p. 212.

11 Jussi Parikka \& Garnet Hertz, 'Interview: Archaeologies of Media Art: Jussi Parikka in conversation with Garnet Hertz,' CTheory, 2010. 
P. Ellis, Picking Up (On) Fragments

As no audiovisual evidence of the realisations of Baird's experiments exist, only the fragmentary archival data and a reenactment from 1967 using the original equipment and featuring the original BBC producer Lance Sieveking, there was nothing beyond the 'representational' of the latter, a media object marginalised to an historical act, yet ripe with 'imaginary' and creative potential. These fragments had the potential to be re-examined and put back together in order to 'see over distance' of nearly a century.

My personal media archaeology began with research trips in the UK to the British Film Institute (BFI), BBC Written Archive Center (WAC) and The National Media Museum in the search for evidence of early television examples, which led me to John Logie Baird's early experimental television drama (in collaboration with the $\mathrm{BBC}^{12}$ ), the Luigi Pirandello play: The Man with the Flower in his Mouth (BBC: 1930), which was broadcast on $14^{\text {th }}$ July 1930 on Baird's 30 line system from the Baird Television Ltd. studio (see Figures 1 and 2) at 133 Long Acre, London (currently a Barbour clothing store on the Ground and First Floor and Robert Walters Recruitment on the floors above - see the section on The Mystery of 133 Long Acre for further details).

The Man with the Flower in his Mouth narrative concerns the meeting in a railway station cafe between The Customer (who has missed his train) and The Man (who is terminally ill with mouth cancer), the latter living vicariously through the lives of those who pass through the cafe. All scenes and dialogue are delivered at the cafe table at which they are seated. This huis clos was technically important at the time as it meant no camera movement which was technically not possible. The play was the first drama to be broadcast on UK television and therefore was a marked creative event and technical development beyond the earlier testing of simply transmitting an image.

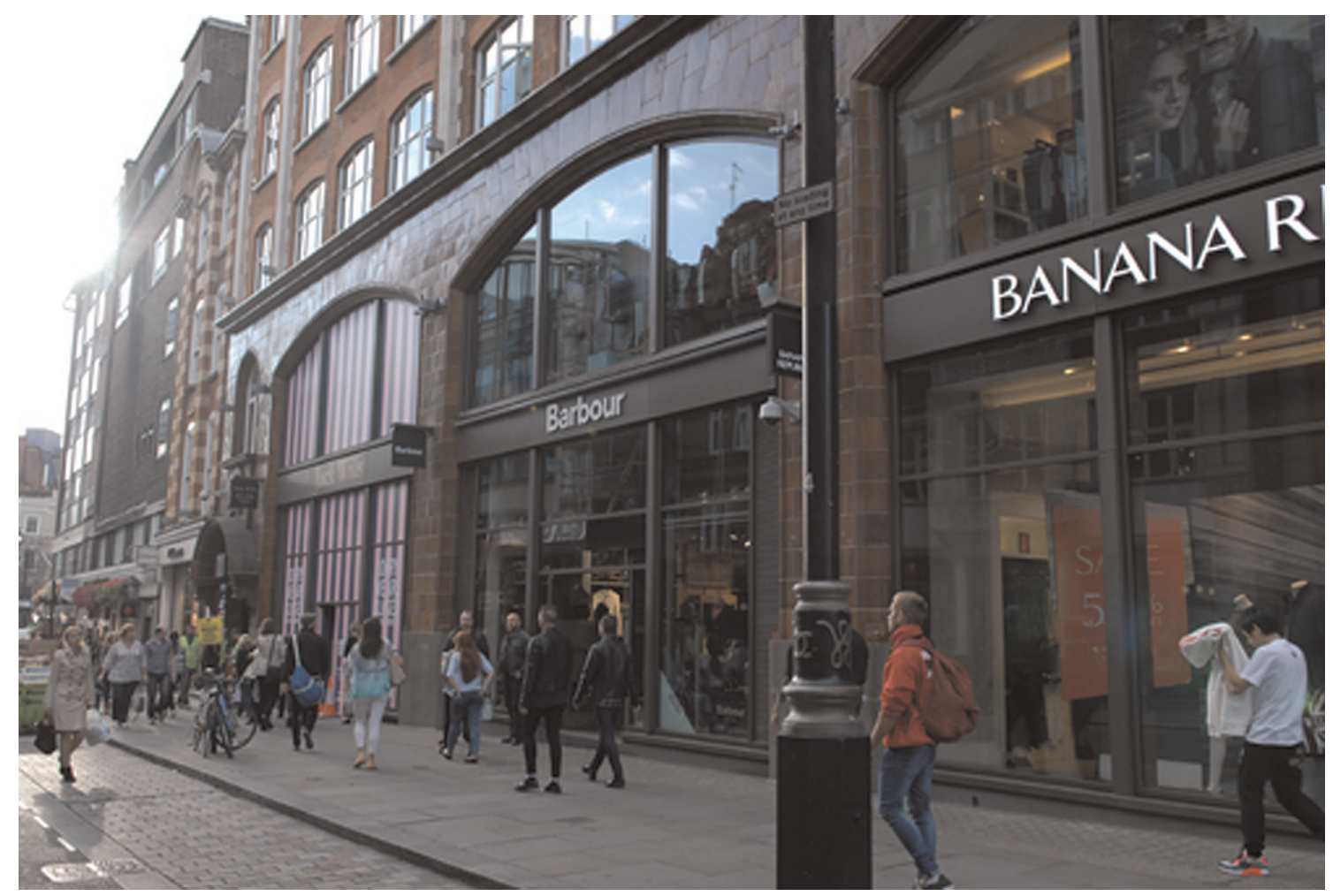

Fig. 1133 Long Acre, London (Barbour Clothing Store), the site of Baird Television LTD. Image by the author.

12 Baird Television Ltd. needed to use the BBC's Savoy Hill transmitter but the BBC were at the time not supportive of television. Indeed, at a subsequent meeting of the Control Board (attended by the first Director-General, John Reith) Reith decided to help Baird with his technical requirements but to not develop his programming aspiratiions (Kamm and Baird, 2002, p. 141-144). 


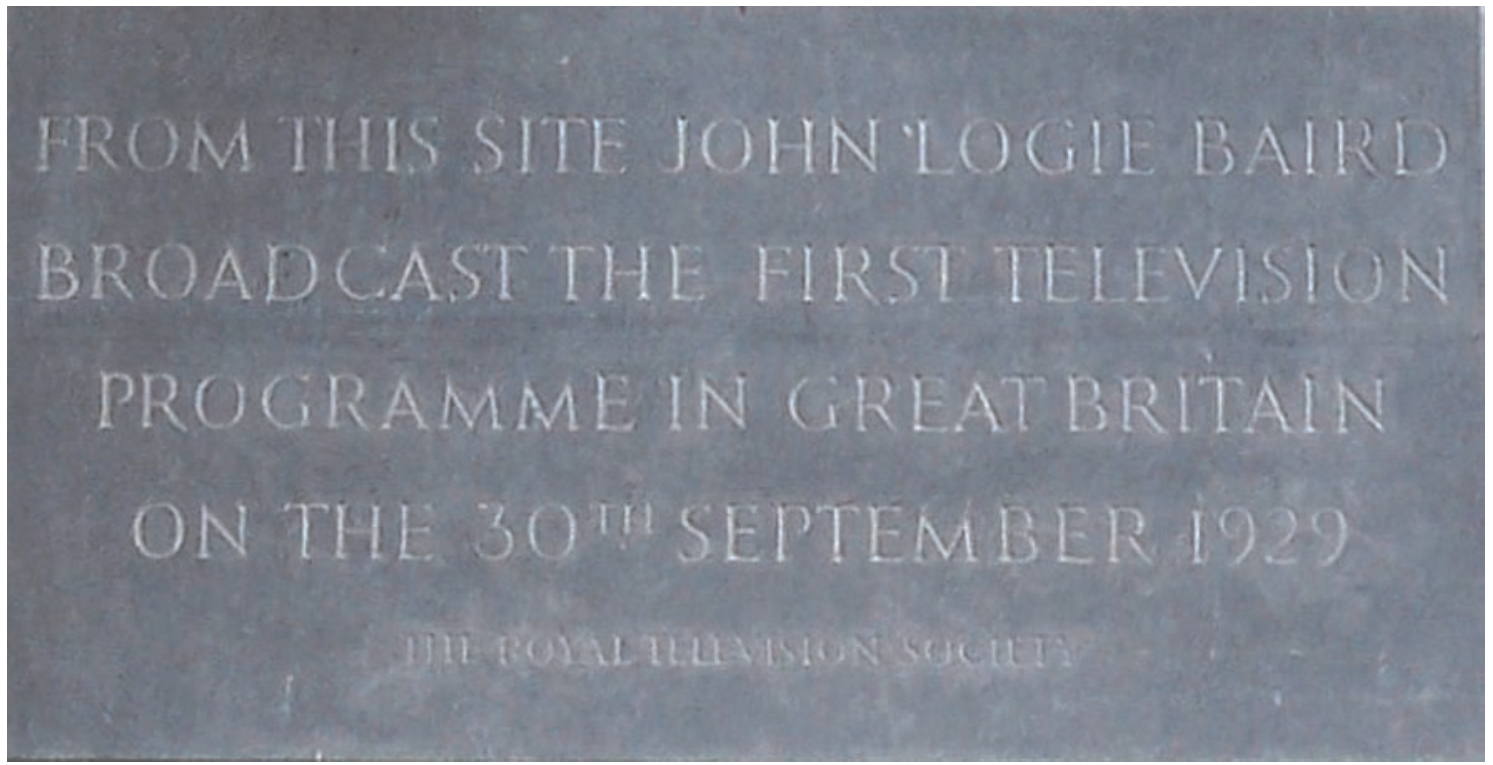

Fig. 2 The Royal Television Society plaque on the wall of Banana Republic Clothing Store, Long Acre, London. Image by the author.

\section{The Archives}

As I began to research and find information about The Man with the Flower in his Mouth, I developed the notion of creating a (as yet undefined) reenactment of the play. The research focused on the archive in terms of the historical documents that relate to the broadcast, the site of broadcast itself as an archive and the considerations of reenactment as 'archival' arts practice. The latter has a rich history of use by artists, notably, Jeremy Deller's Battle of Orgreave ${ }^{13}$ which explores the emancipatory potential of participation, Rod Dickinson's Nocturn: The Waco Reenactment ${ }^{14}$ which reenacts an event that had wide media coverage and seeks to harness the viewers' understanding of this mediation in an act of destabilisation, and Marina Abramovic's Seven Easy Pieces, ${ }^{15}$ which develops this destabilization in seven reenactments of significant art historical events at which the artist was not present, instead developing works that rely on witnesses and traces of recordings, developed by the artist into performance. The latter resonated the most with my developing project.

I then investigated how the archives and their contents and reenactment theories and practice might all come together to facilitate creative practice, through the relationship that the space between presence and absence dynamic invites between the archive and contemporary reenactment arts practice. To paraphrase Steve Rushton, the issue then becomes not what archive is but what archive does, which is equally applicable later in this article, relating to the actual context of reenactment whereby "the issue then becomes not what reenactment is but what reenactment does." 16

The early visits to the BFI library ${ }^{17}$ presented press cuttings from the fledgling journal Television and newspapers from 1930. Some duplicated material was discovered in the John Logie Baird Special Collection housed at the BFl's Berkhamsted National Archive. A research visit to the BBC Written Archive Centre in Reading uncovered the original script from $1930^{18}$ (see Figure 3), newspaper and journal reviews of the 1930 productions, and online research sourced

13 Jeremy Deller, 'The Battle of Orgreave,' 2001.

14 Rod Dickinson, 'Nocturn: The Waco Re-Enactment,' 2004.

15 Marina Abramovic, Seven Easy Pieces, 2007.

16 Steve Rushton, Tweedledum and Tweedeledee resolved to have a battle in Experience, Memory, Re-enactment, Piet Zwart Institute and Revolver, 2005, p. 11

17 BFI Special Collections, London, England, Baird Collection, Television before 1939 Collection, Parts I and II.

18 BBC Written Archives Centre, Reading, R5/7/1, 924/MAN, 14 July 1930. 
the El Carretero soundtrack (digitised by Don McLean from the original 78rpm disc kept by Lance Sieveking), and especially commissioned background images by artist C.R.W. Nevinson. ${ }^{19}$

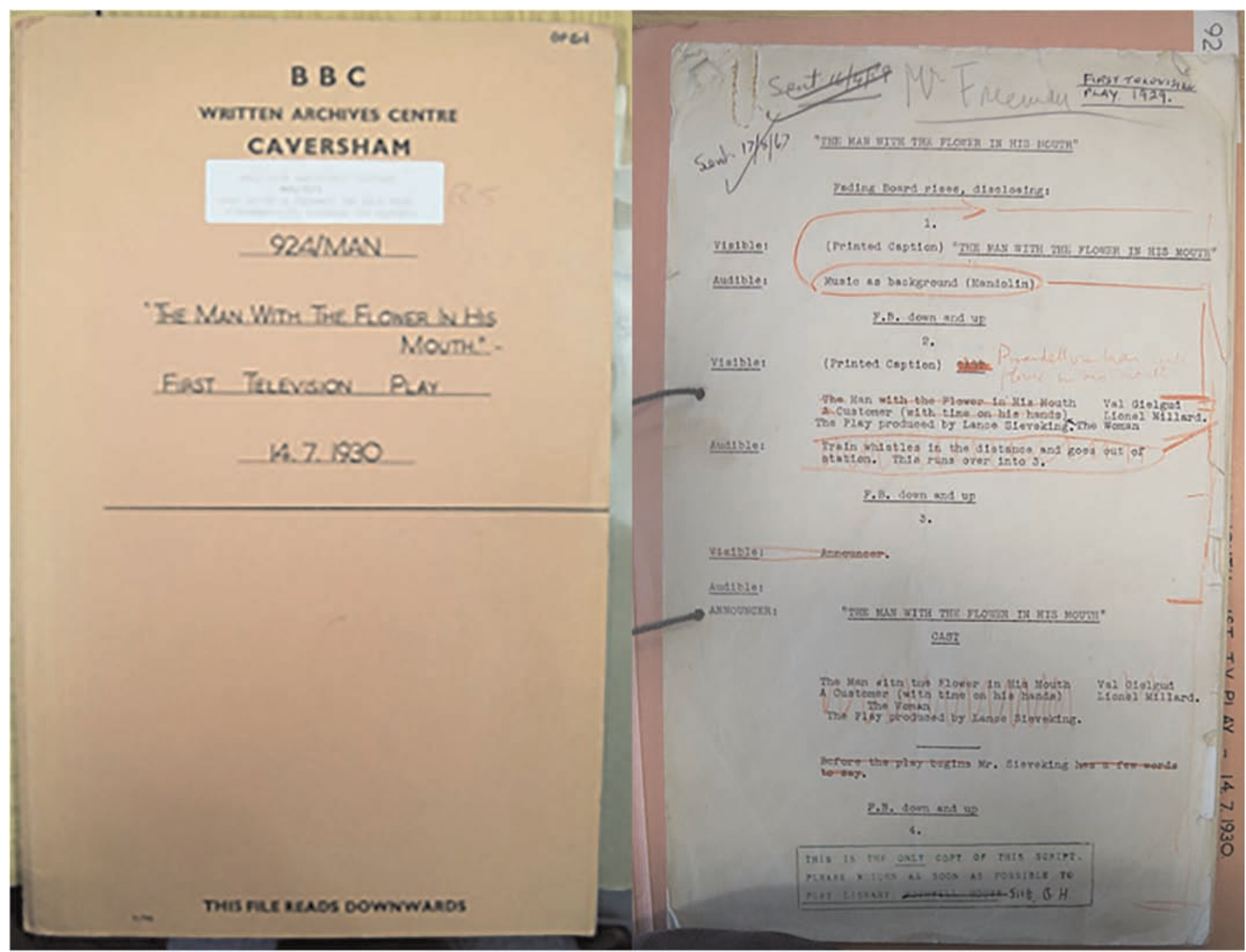

Figs. 3 and 4 The original script for the Broadcast of The Man with the Flower in His Mouth. Image by the author, by permission of BBC Written Archive Centre, Reading, UK.

\section{Trace, Testimony and the Energy of the Moment}

The fragmentary traces left in the various archives invited interrogation of how these objects might be (re)used through a parallel investigation of how the archive might function itself as a resource for creativity. In an earlier article in Communications, ${ }^{20}$ I contextualised this research in more depth by way of framing the project at a research and development stage. The section here develops that argument into the current practice. 


\subsection{Memory Places}

Discussing 'memory places,' Paul Ricoeur proposes in Memory, History, Forgetting that "it is not by chance that we say of what has occurred that it took place." History and memory are competing and incomplete, but related dynamics: a "tie between memory and place results in a difficult problem that takes shape at the crossroads of memory and history, which is also geography." ${ }^{21}$

In his text, Ricoeur then concentrates on the notion of the archive itself, suggesting that "the archive ... presents itself as a physical place that shelters the destiny of ... the documentary trace. But the archive is not just a physical or spatial place, it is also a social one." 22 He suggests then that 'trace' is not a fixed entity but part of a discursive dynamic between the archive and its social use: "trace, document, and question thus form the tripod base of historical knowledge." 23 That is, we are active agents in the ways in which we make sense of objects and actions from the past: it is by ' "understanding the present by the past' and correlatively 'understanding the past by the present' - that the category of testimony comes on the scene as the trace of the past in the present." ${ }^{24}$

\subsection{Memory and History}

To return to the dialectic of memory and history for a moment, in Between Memory and History: Les Lieux de Mémoire, Pierre Nora discusses sites of memory (lieux de mémoire) suggesting that "our interest in lieux de mémoire ... has occurred at a particular historical moment, a turning point where consciousness of a break with the past is bound up with the sense that memory has been torn." ${ }^{25}$ If Nora is suggesting 'sites of memory' are a socially-constructed phenomenon, then both personal and social memory are unstable connections to the past and therefore problematic, "with the appearance of the trace, of mediation, of distance, we are not in the realm of true memory but of history ... [which is just] a representation of the past ... always problematic and incomplete." ${ }^{26}$ Equally, memory is dynamic and constructed, "in permanent evolution, open to the dialectic of remembering and forgetting ... a bond tying us to the eternal present." ${ }^{27}$ Further, the act of mediating history itself is problematic and dynamic as the process is affective in relation to the archival traces. As John Peters suggests in paraphrasing Marshall McLuhan: "The medium is the message in history too." 28

The relationship between these theoretical positions and the media archaeological reenactment project became increasingly clear and are crucial to the framing of what would become the arts practice for the research project, titled 30 lines / 60 seconds. History, document, trace and memory are all dynamic agents in the ways in which we might look at the historical act of Baird's broadcast of The Man with the Flower in His Mouth and its reenactment, in which the media objects of the Baird archive are integrated into the present in the process of enacting, animating and questioning their traces. The archives that contain the traces can no longer be seen as the keepers of unquestioned truths, which will become clear when the stability of the archive is examined further in the next section. Instead, the archive and its traces of history and memory must be seen as fluid and open, perhaps exposing the immateriality of the energy of the moment in 1930, encapsulated in the ghost-like traces of the first moments of 'seeing over distance,' that potentially reside in our memories, too.

21 Paul Ricoeur, Memory, History, Forgetting, The University of Chicago Press, 2004, p. 41.

22 lbid., p. 167.

23 Ibid., p. 177.

24 Ibid., p. 170.

25 Pierre Nora, 'Between Memory and History: Les Lieux de Mémoire’ trans. Marc Roudebush, Representations, 26, Special Issue: Memory and Counter-Memory, Spring 1989, p. 7.

26 Ibid., p. 8.

27 lbid., p. 8.

28 John Peters, "History as a Communication Problem" in Explorations in Communication and History, ed, Barbie Zelizer, Sage, 2008, p. 21. 


\section{The Mystery of 133 Long Acre}

From the initial research stages, there were parallel investigations into the broadcast from the perspectives of the technical aspects, the media objects and the location of the broadcast. As I have written before, subsequent visits to the BFI archive and 133 Long Acre demonstrated that there were some instabilities in the relationship between the 'truth' of the archive and its cultural signposting. Historically, the Baird broadcast and his company's location determines that his studio was at 133 Long Acre, and, as can be seen from Figure 5 (image taken in 2010), 133 Long Acre was the building to the right of a set of three, hence the Royal Television Society (RTS) plaque on the right hand column (in the shadow of the lamppost - close-up in Figure 2), identifying it as Baird's studio. It is worth noting that the image for Figure 5 was taken when the building was in transformation and the large numbering '133' has disappeared as can be seen in Figure 1.

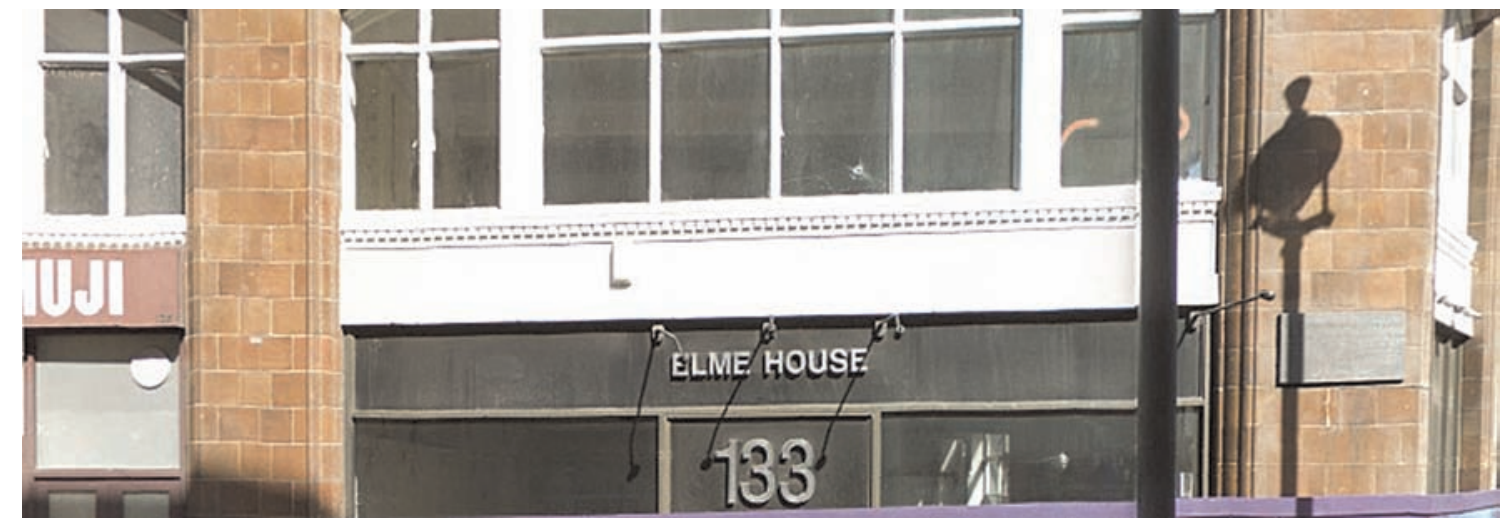

Fig. 5 Image showing the numbering and plaque for 133 Long Acre, London in 2010 as being on the right of the three adjoined buildings. Image by the author.

However, in Donald McLean's book Restoring Baird's image ${ }^{29}$ the 133 Long Acre of 2010 was in fact the Car Specialist business at No.132 Long Acre. Baird's studio (see Figure 6) is clearly in the central building (named as 133, with a Baird Television sign stating 'First Floor,' which can be seen in the enlarged image in Figure 7). This suggests that between 1930 and 2010, the numbering of the buildings in Long Acre changed. Incidentally, in the new development, Banana Republic, which occupies what was Elme House in 2010, is currently trading with the address of 132 Long Acre. The 'real' studio is therefore within the central building at the site of the Barbour clothing company, which trades from 133 Long Acre. The RTS plaque is signposting Baird's premises to the wrong building.

I now knew the site of the original broadcast in terms of which building it was in and where the subsequent reenactment would take place ... almost. In terms of the location of Baird's studio, notwithstanding the evidence of the image in Figure 6 where an outside broadcast van can be seen with cables going up through the window of the Baird premises on the first floor, research had positioned Baird's presence in the correct part of the building, but there was still some confusion as to the exact whereabouts of the studio. Baird technician Desmond Campbell states in an audio interview that "the studio in those days was upstairs," ${ }^{30}$ but he doesn't state 'upstairs' from exactly where. However, Antony Kamm and Baird's son Malcolm had suggested when discussing where the dignitaries viewed the broadcast that on "the flat roof of Long Acre, four storeys above the studio, a select audience of scientists and representatives of the press saw the transmission." ${ }^{31}$ Counting down from the roof, this places the studio on the first floor. With this evidence and the image of the sign and the outside broadcast van's cables going into the first floor, I focused on this location for the reenactment, which was in transition from 'Muji' (see Figure 5) to 'Barbour' (see Figure 1). 


\section{VIEU}

P. Ellis, Picking Up (On) Fragments

Clearly, the issue of location is problematic in relation to the reenactment of an event if a 'site of memory' is taken literally, especially in the context of trace, document, history and (cultural) memory as discussed earlier.

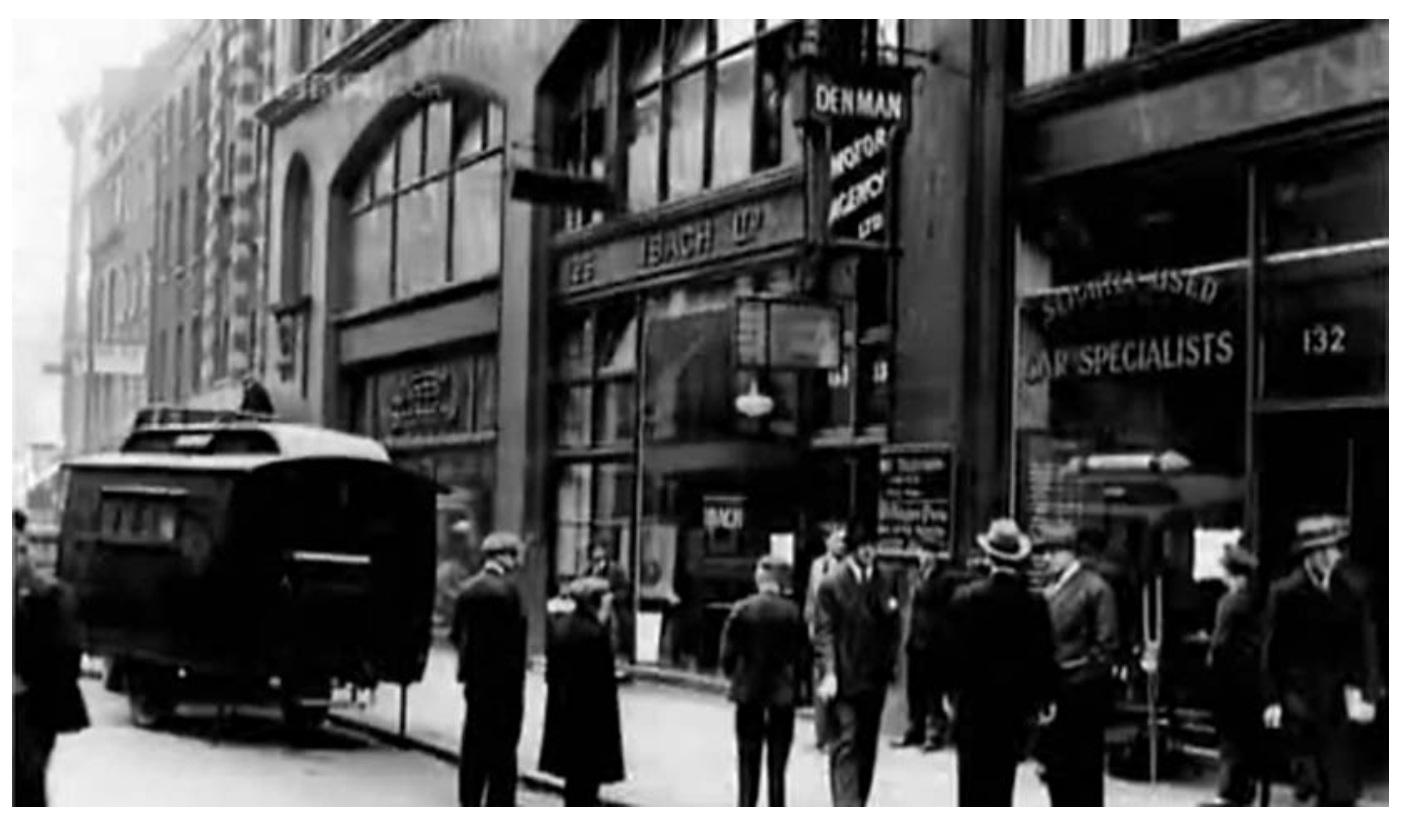

Fig. 6 Long Acre in 1931. Restoring Baird's image (2000, p. 179). Note the numbering above the Baird Television sign. 133 Long Acre is the upper central building. Published by permission of Royal Television Society. Copyright: Royal Television Society.

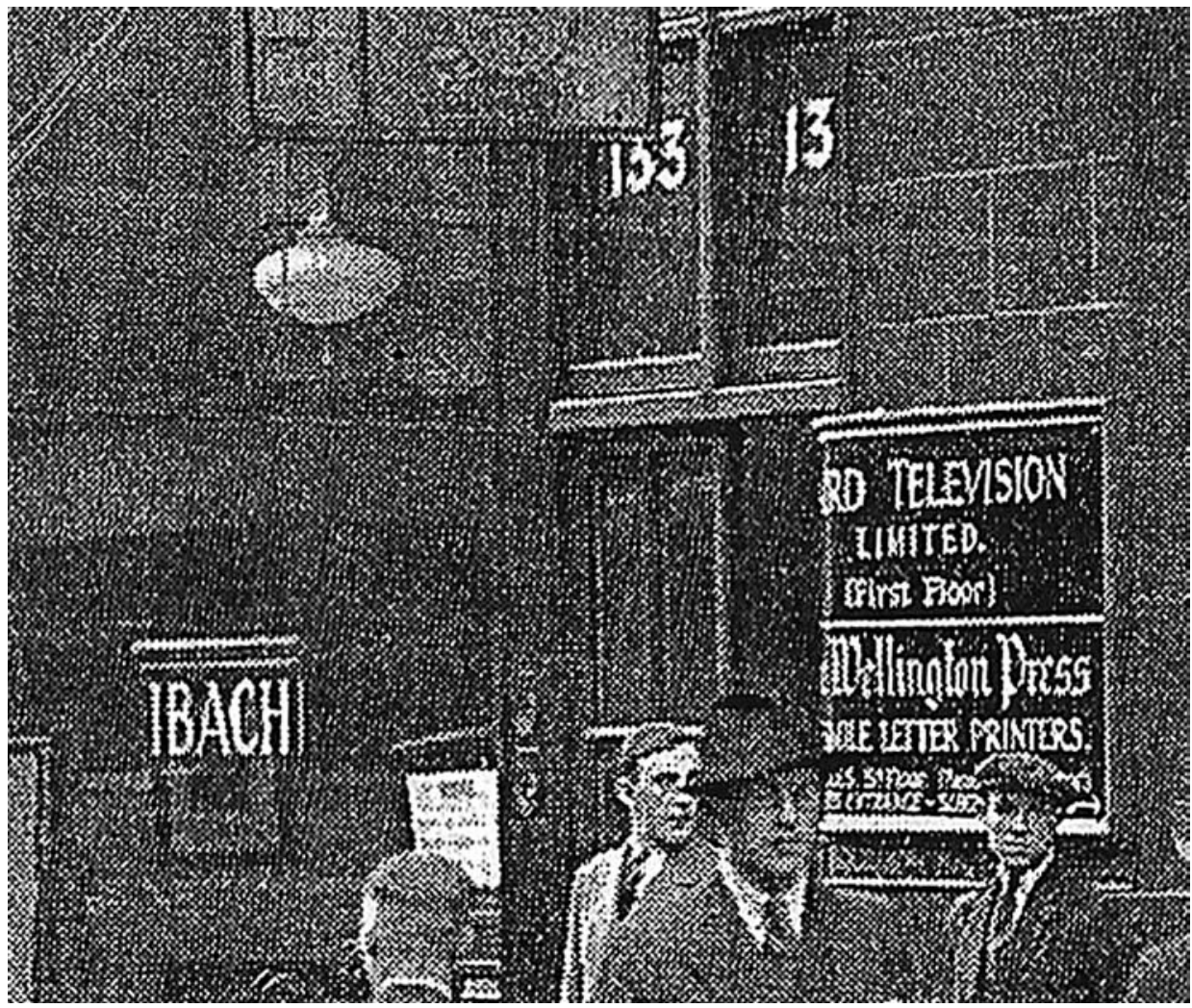

Fig. 7 Enlargement of above image. Published by permission of Royal Television Society. Copyright: Royal Television Society. 


\section{The Reenactment Process}

In the light of the considerations of the instability of the historical traces from the archive and the creative potential of their (re)use, I interrogated the reenactment process and how the project would develop from sifting through the pieces of the jigsaw of the archive and its traces. Sven Lütticken suggests that "art can examine and try out ... forms of repetition that break open history and the historicist returns of past periods; it can investigate historical moments or eras as potentials waiting to be reactivated, in forms that need not resemble anything." 32

The reenactment process can therefore foreground how participation for all agents in a reenactment event which is "anything but static" ${ }^{33}$ facilitates the interaction and integration of the kind of unstable traces that have been identified with objects and testimonies from the archive, presenting historical places and spaces that can be dynamic palimpsests, in turn enabling open, interpretative reenactment processes to occupy the space between presence and absence. This dialogic process between the past broadcast and present reenactment, the construction and re-presentation of the images and sounds (both contemporary and historical), with an "archive fever" that might "burn with passion" in the "desire for the archive ... to return to the origin," ${ }^{34}$ works the archive as, and into, a creative act.

\section{The Reenactment Practice: 30 lines / 60 seconds}

During several years of research, negotiation and planning and much help from John Logie Baird's son, Malcolm, grandson lain and Don McLean, I was (virtually) introduced by Don to Gary Millard in Australia who had developed a digital emulator for narrowband TV. Gary created software Video2NBTV - The Big Picture (see Figure 8), which processed the digital webcam image through a 30 line Baird emulation process using the computer's soundcard in a quasi loop between the digital-analogue-digital processes. The result is the creation of an intriguing aesthetic of the constraint into 30 'lines' of pixels, degrading the image and forming phantom-like and trace-like images. These 'ghosts' invite a discourse between participants, the play (past and present) and the place of 133 Long Acre (past and present) through the technical emulation.

This image is then streamed via Wirecast streaming software (see Figure 9) and this stream is displayed on an Apple iPhone 4 (see Figure 10) in the performance space on its $5.08 \mathrm{~cm} \times 7.6 \mathrm{~cm}$ screen (roughly the same dimensions as Baird's original).

\section{Participatory Performance at Kunsthalle Project Space, Vienna, 2013}

The work was originally performed during the opening night of the 2013 HERA (Humanities in the European Research Area): 'Technology, Exchange and Flow: Artistic Media Practices and Commercial Application' at the Kunsthalle, Vienna and at the Dutch National TV Archives in Hilversum. The reenactment was participatory (Figure 11 shows participants), allowing for the audience to interact with lines of the play from the original script (shown on cue cards in both English and German, see Figure 12) each for a segment of 30 seconds duration. For this performance, I played the character of The Man and 17 participants played the character of The Customer. Readers will also be aware of a chequered 'fading board' as one of the props. This is also noticeable in rare photographs of the original performance and ran on a wooden runner. There are moments where the actors move closer into shot and Baird noticed that the image would destabilise when this occurred. ${ }^{35}$ However, using the board as an editing device discounted this instability.

32 Sven Lütticken, Life, Once More: Forms of Reenactment in Contemporary Art, Witte de With Center for Contemporary Art, 2005 , p. 60.

33 Steve Rushton, Tweedledum and Tweedeledee resolved to have a battle in Experience, Memory, Re-enactment, Piet Zwart Institute and Revolver, 2005, p. 8.

34 Jacques Derrida, Archive Fever: A Freudian Impression, The University of Chicago Press, 1996, p. 91.

35 Donald Mclean, The Dawn of Television Remembered, transcript, self-published, 2004, p. 14. 


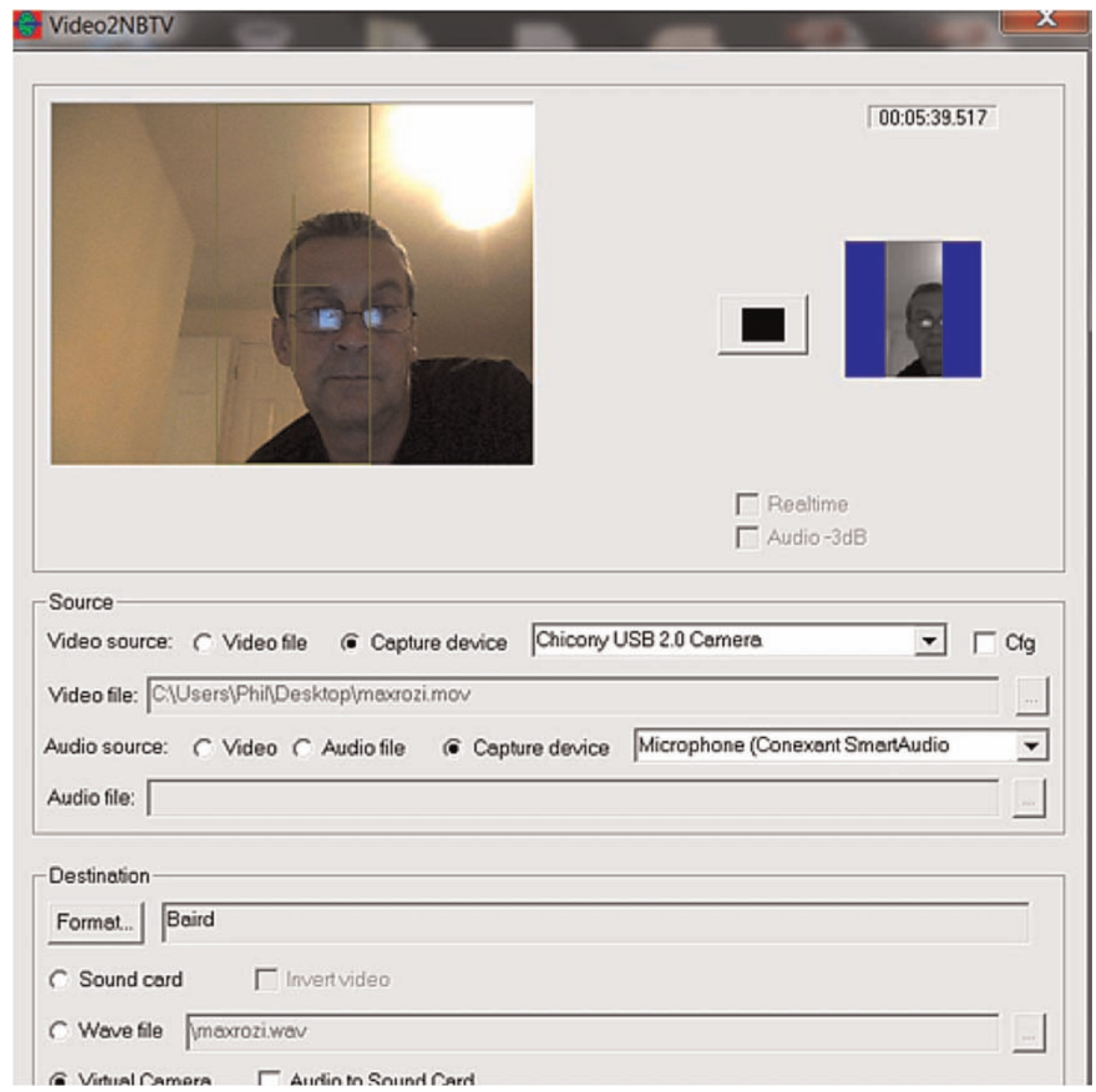

Fig. 8 Video2NBTV - The Big Picture, emulating 30-line Baird TV. Image by the author.

In my reenactment, I used the board as a similar editing device to divide the segments (the script refers to "FB Up" and "FB Down" to signal the edits - see Figure 12 for the German translation including the 'FB' instructions).

Each segment was filmed on a webcam in the performance space. The latter represents Baird's small studio at 133 Long Acre, London and was a marked matted space $120 \mathrm{~cm} \times 120 \mathrm{~cm}$ (the dimensions of Baird's studio), so all props and equipment were contained within this space. The webcam (and accompanying spotlight) was static at the back of the space with the participants (there are two speaking male characters and a silent female character) moving in and out of the camera's field of vision.

The segments were edited together overnight and then displayed on the iPhone (which can just be seen on the near left of the table in Figure 13, showing the studio set-up) as a twenty-two-minute video for the rest of the exhibition, with the traces of the 'studio' left intact in the space. The final work that was streamed on the iPhone can be seen in this video. 


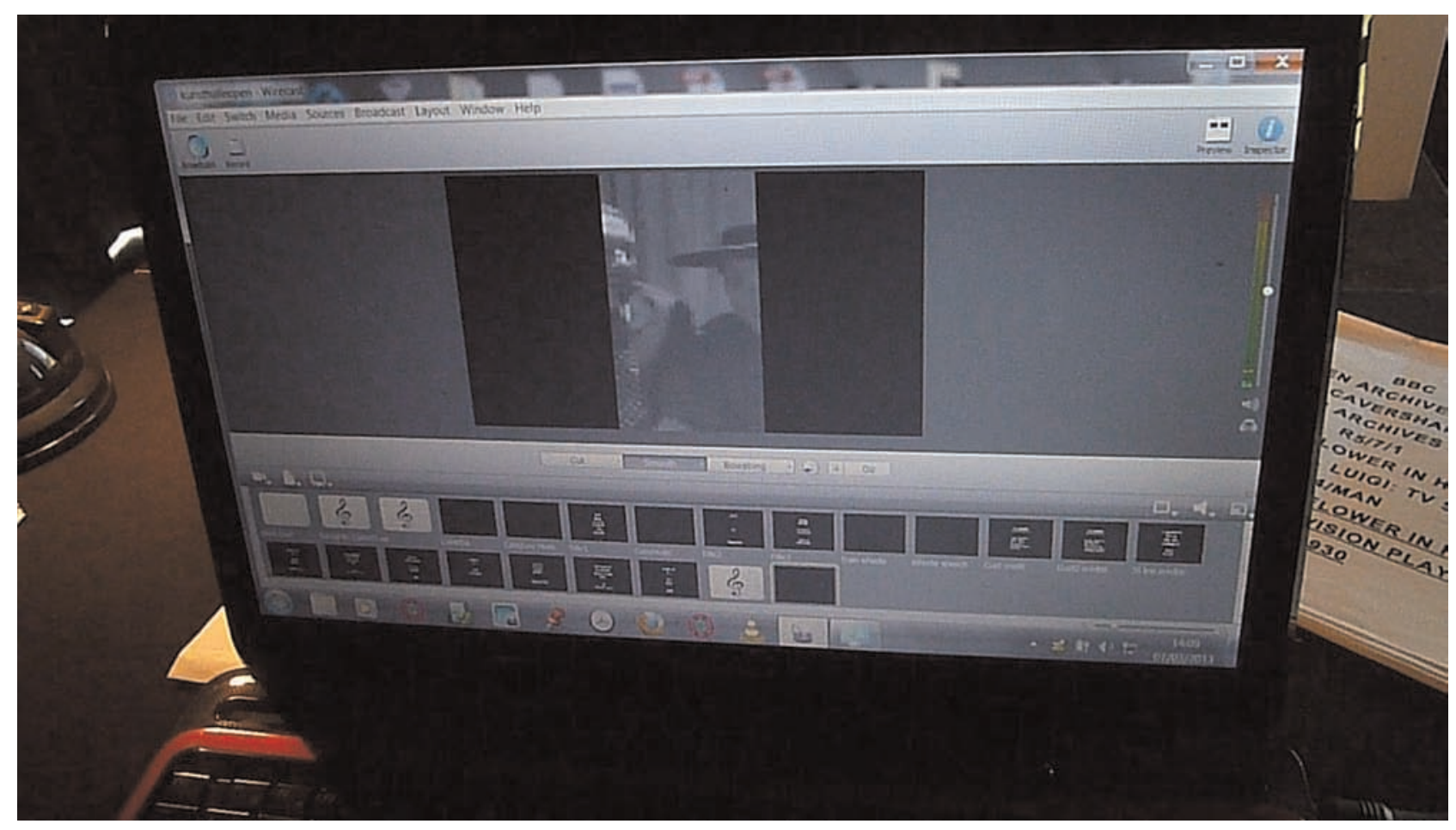

Fig. 9 The 30 line emulation streamed through Wirecast. Image by the author.

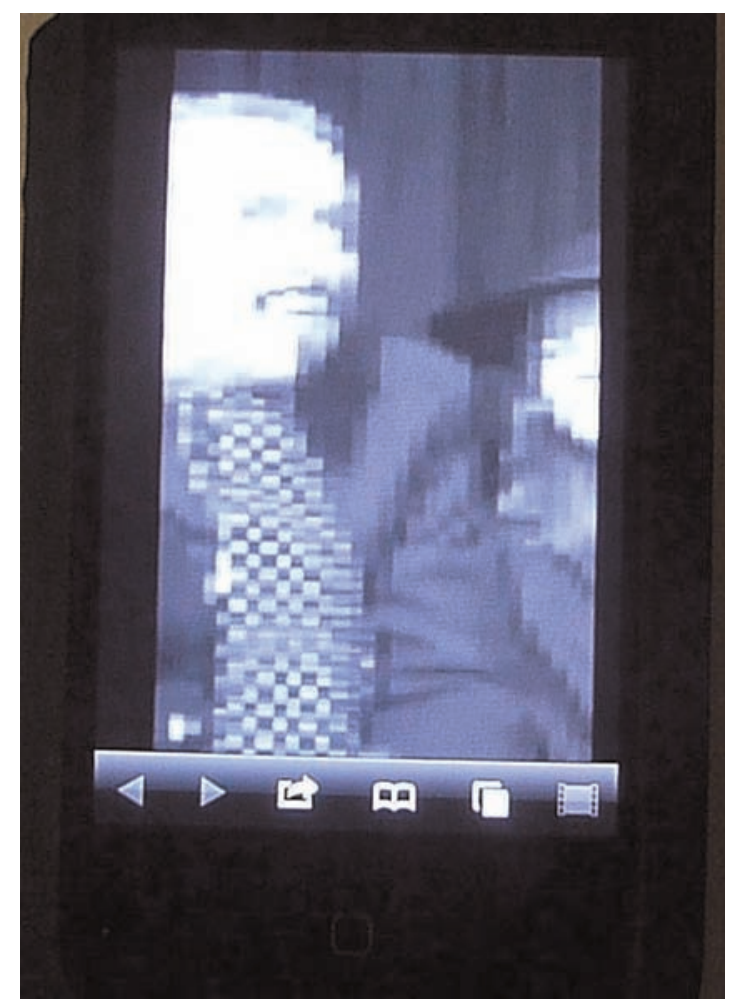

Fig. 10 The resulting and final image of the stream on an iPhone 4. Image by the author. 


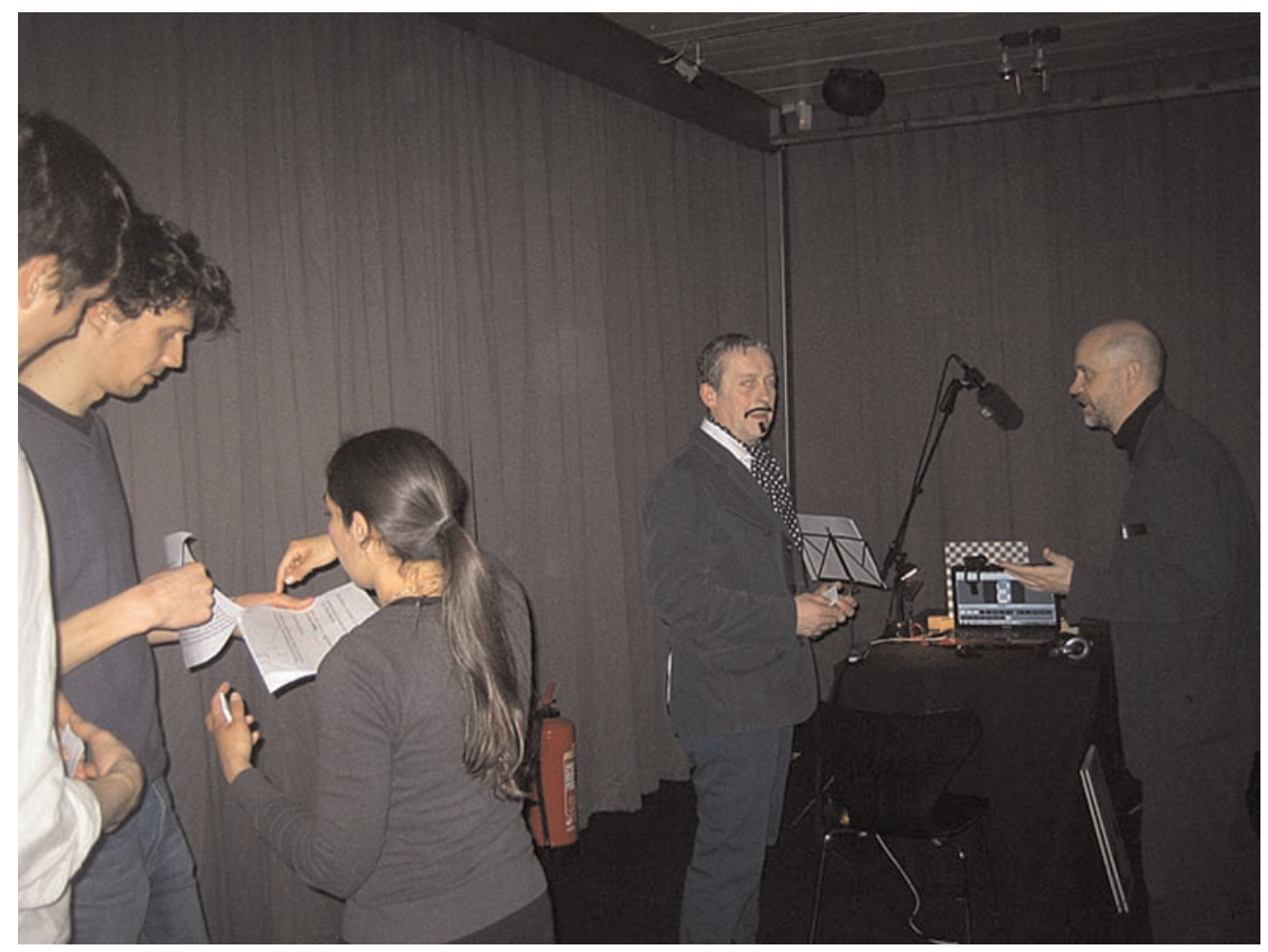

Fig. 11 Participants being briefed for the reenactment of The Man with the Flower in his Mouth at Kunsthalle Project Space, March 2013. Image by the author.

MANN: Oh, natürlich haben Sie das nicht ... weil Sie nicht krank waren ... Aber selbst kranken Menschen fällt es nicht immer auf - es wird alles so hingenommen als gehöre es zu dem, was verkehrt mit ihnen ist.

F.B. runter und hoch (MUSIK)

Straßenszene.

MANN: (OFF) (sehr langsam) Und trotzdem, oft sitzen einige von ihnen da und betrachten so sorgfältig einen ihrer Finger, wie er sich hin und her bewegt, sodass bedeutungslose Buchstaben und Zahlen auf dem lackierten Arm des

F.B. runter

\section{(KEINE MUSIK)}

Fig. 12 German Translation of the original script for the reenactment of The Man with the Flower in his Mouth at Kunsthalle Project Space, March 2013. Image by the author. 


\section{VIEU}

P. Ellis, Picking Up (On) Fragments

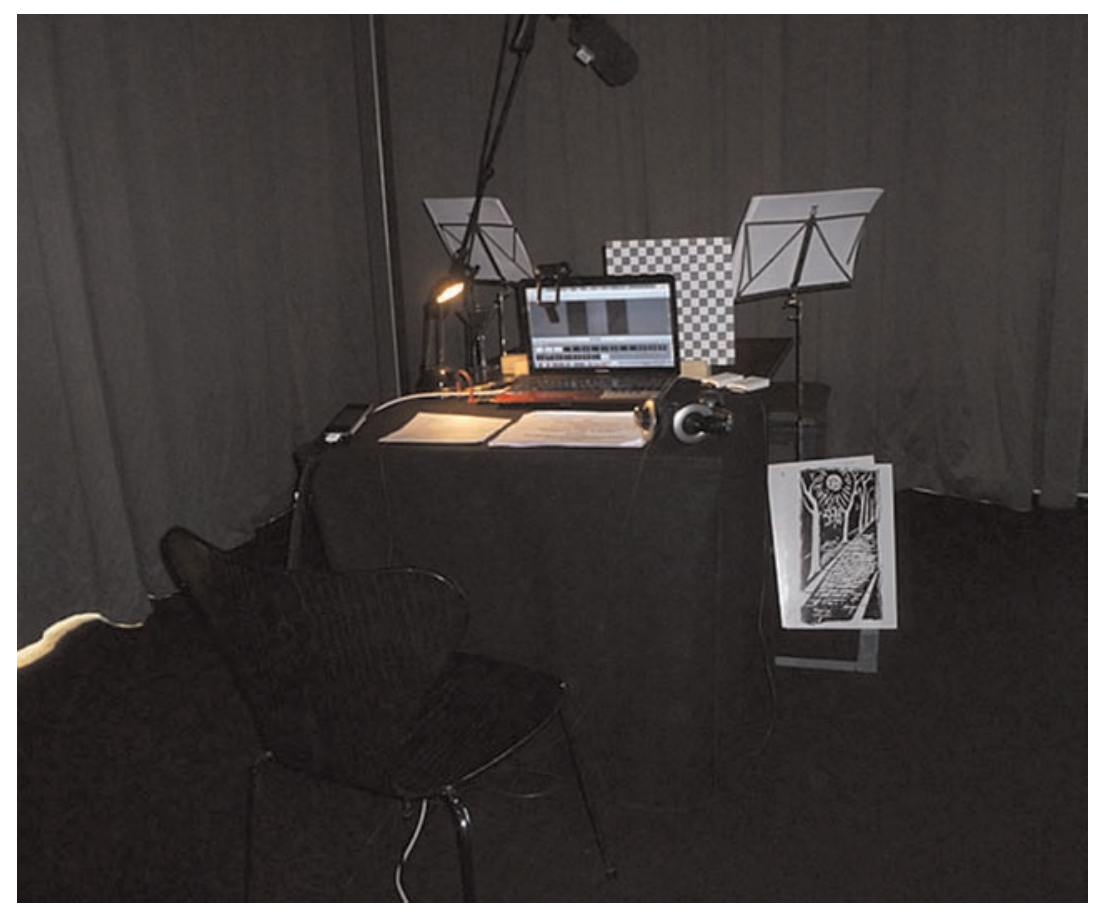

Fig. 13 Studio set-up from 30 lines / 60 seconds at Kunsthalle Project Space, March 2013. Image by the author.

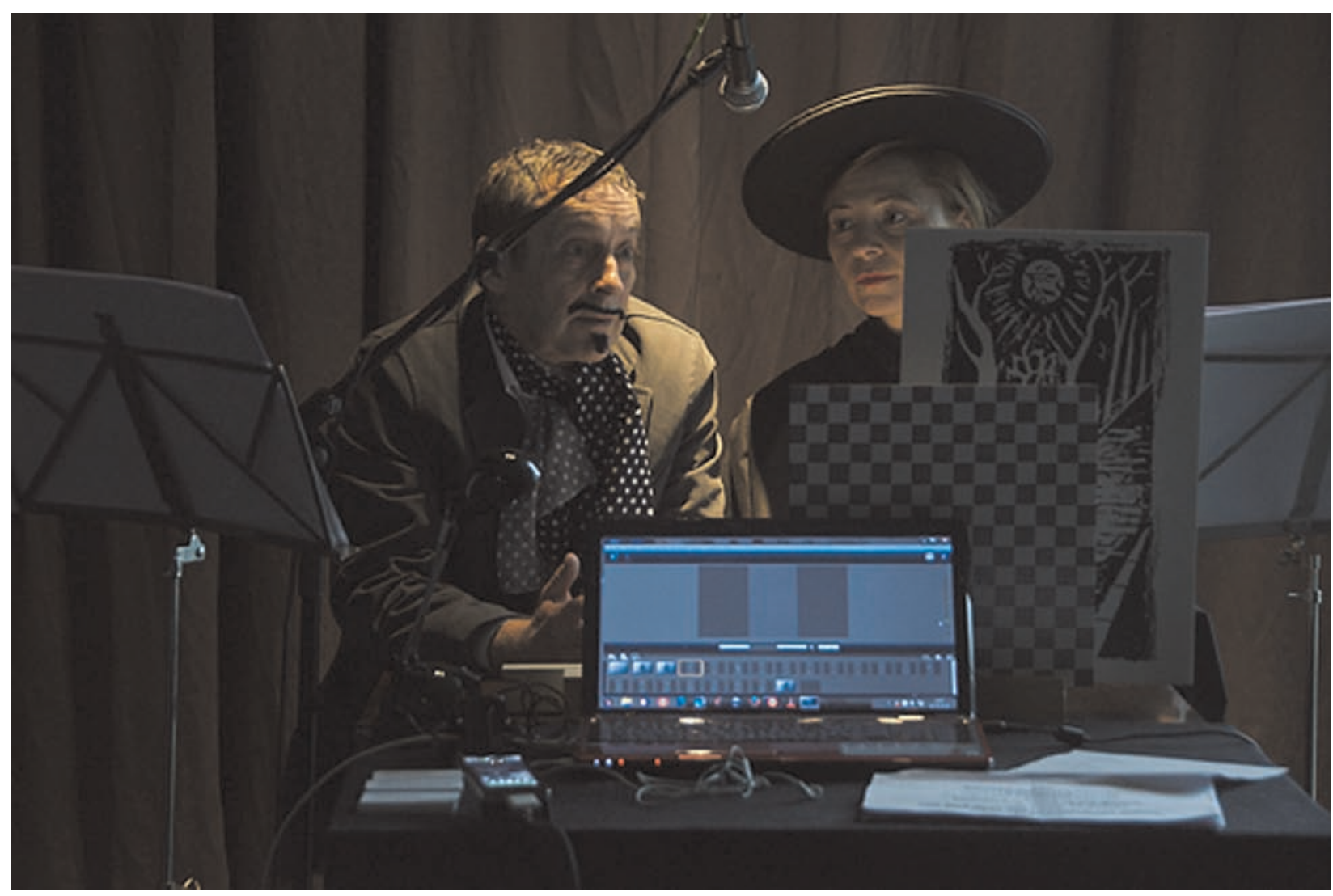

Fig. 14 Publicity still from 30 lines / 60 seconds at Kunsthalle Project Space, March 2013. Image by the author. 


\section{Rehearsal for Long Acre Reenactments at 'Archaeologies of Media and Film' Conference, Bradford University, September, 2014}

I had been discussing the proposed reenactment with Barbour at 133 Long Acre in early 2014 and they had been most supportive of the project and it was agreed that I would perform the work with members of staff who work at 133 Long Acre as the actor/participants in late September.

Ahead of the event, I gave a contextual talk and limited performance by way of rehearsal at the 'Archaeologies of Media and Film' Conference at Bradford University in early September. At the event, delegates, including Jussi Parikka, reenacted segments of the play (see Figure 15).

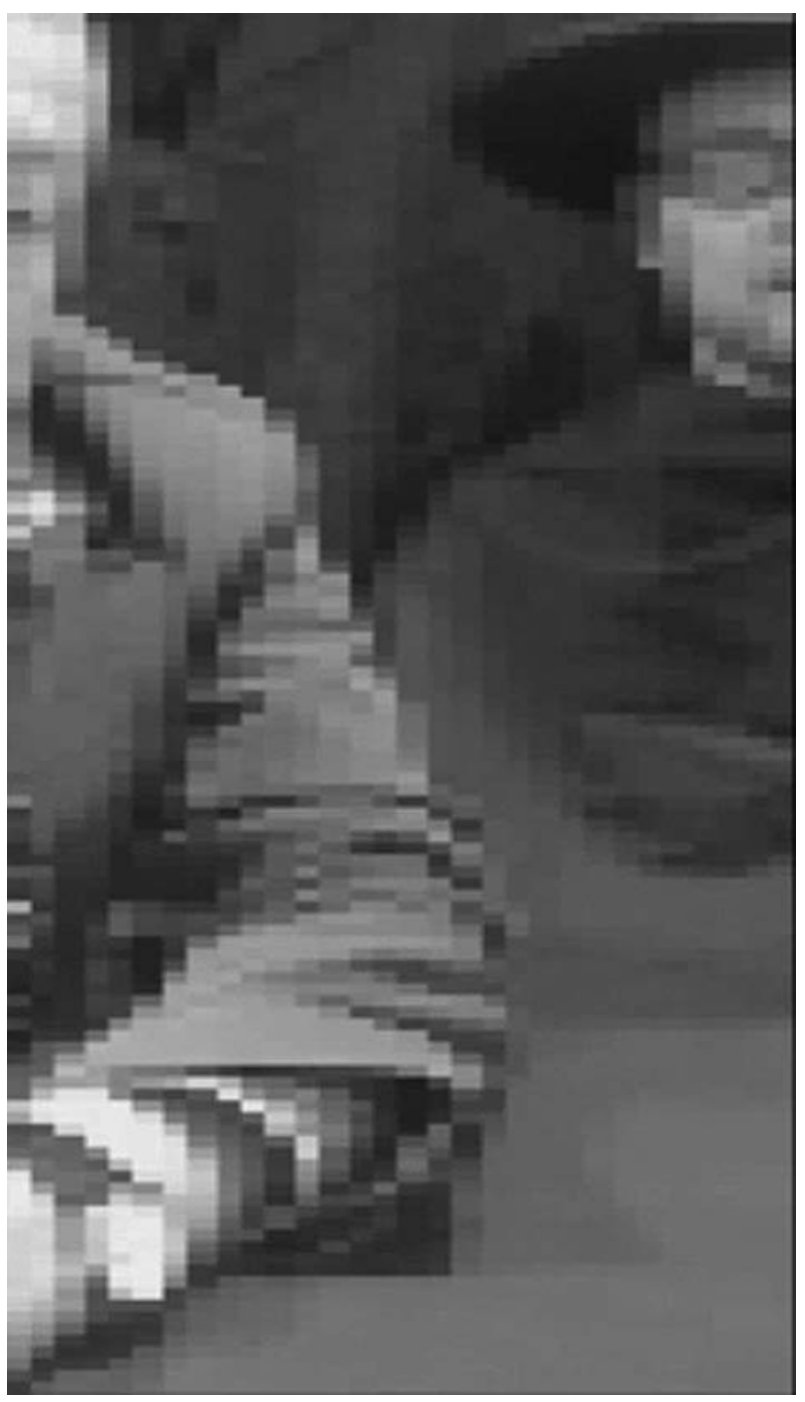

Fig. 15 Phil Ellis and Jussi Parikka, Rehearsal for 30 lines/60 seconds at Archaeologies of Media and Film. Bradford University 2014. Image by the author. 


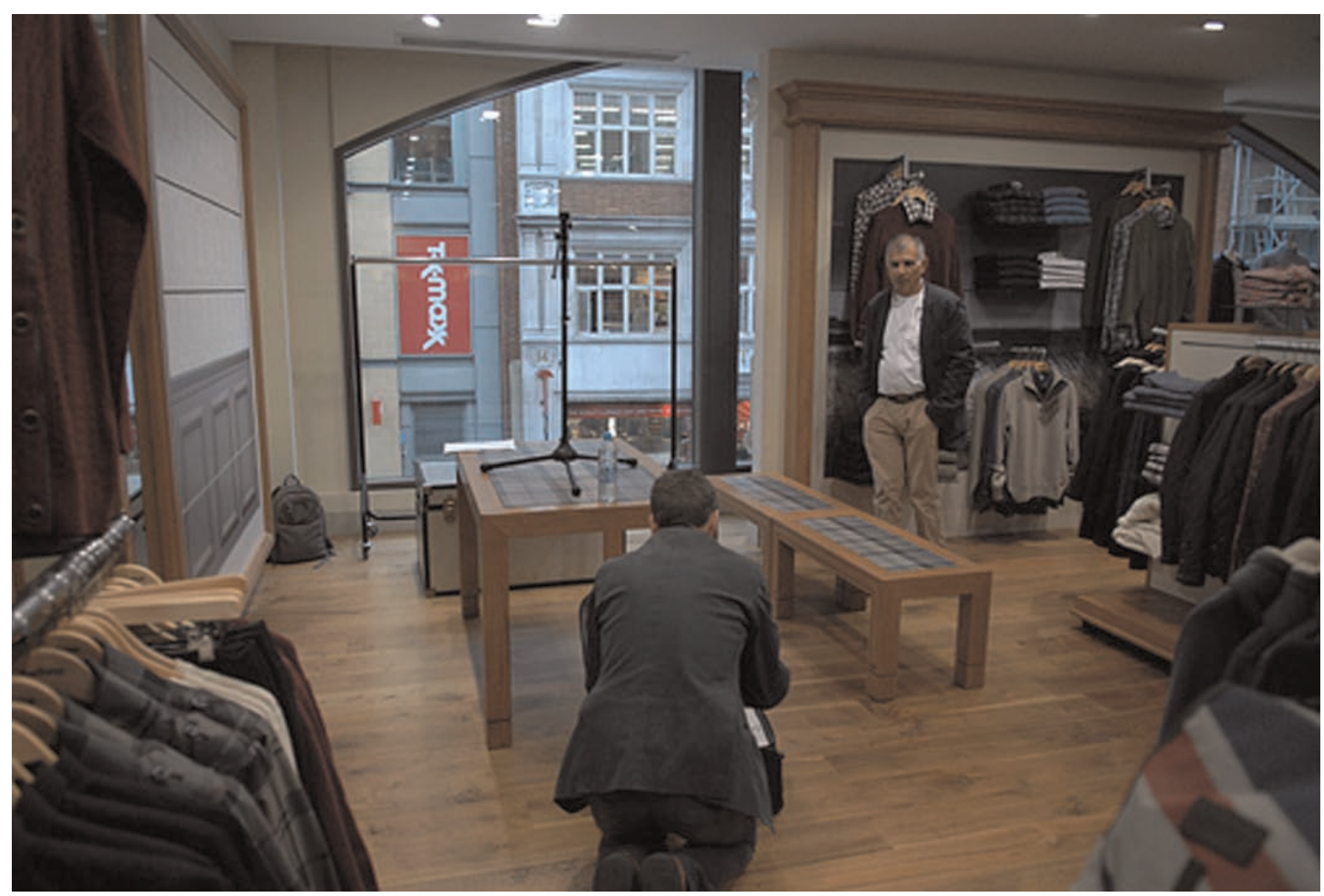

Fig. 16 The author setting up the equipment for 30 lines / 60 seconds at 133 Long Acre, London, in front of the first floor window in Barbour Clothing Store, September 2014. Image by the author.

\section{The Final Reenactments at 133 Long Acre, London on September $26^{\text {th }} 2014$}

During discussions with Barbour in the late Spring/Summer of 2014 it became apparent that there was much interest in the project from the staff and management. They had no idea that they worked in a space that had media historical significance. The manager, Mark Sharrad, was most supportive and made all resources available, including stirring interest in staff members to take part in the reenactment. Among the staff were three actors who between them had film, television and theatre experience.

I decided that there would therefore be two reenactments. I would create a participatory one with members of staff taking part, recording the segments as I had done in Vienna and Bradford. I would then stream a live reenactment in one single take using the three aforementioned actors. The reenactments would take place as an artwork during the store's opening hours in front of the central window of the first floor (where the OB leads enter the building in Figure 6).

The reenactments took place on Friday $26^{\text {th }}$ September 2014 and were streamed live on pumar.org via Wirecast streaming software, as explained above. An interview with the three actors reflecting on their experiences can be seen in this video. 


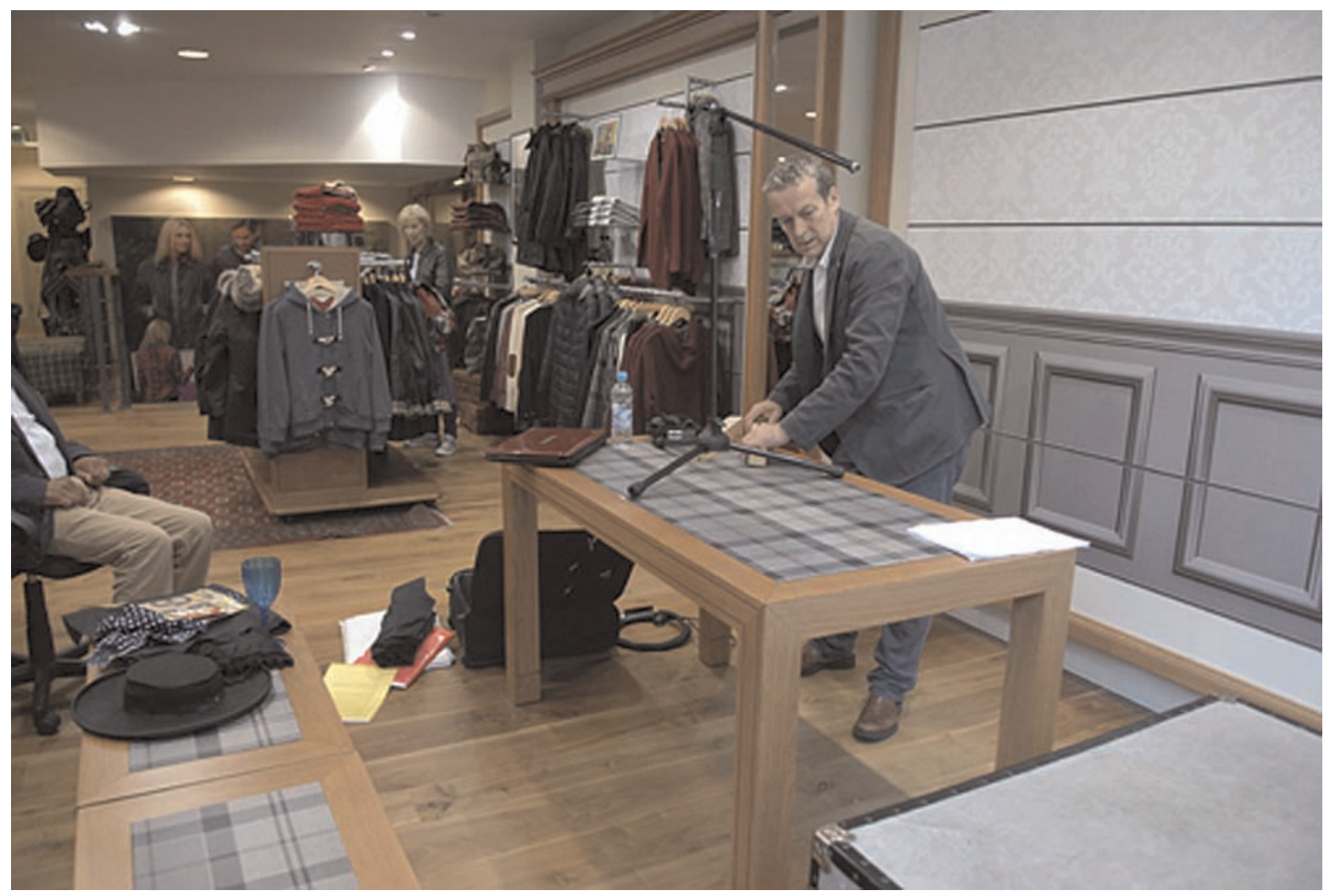

Fig. 17 The author setting up the equipment for 30 lines / 60 seconds at 133 Long Acre, London, in front of the first floor window in Barbour Clothing Store, September 2014. Image by the author.

Figures 16-19 show the setting up of the reenactment equipment at Barbour with the help of Chris Rodrigues who assisted in the project, along with David Hooper.

The Baird 30 lines / 60 seconds reenactment at 133 Long Acre facilitates active engagement with the material of the play through the workers of Barbour at 133 Long Acre, which opens a dialogic relationship between past and present technologies and conditions undertaken by fully participatory (re-)authors and (re-)actors. Reenactment processes undertaken under media archaeological methodological conditions offer the potential to destabilise and agitate the position of both viewers and participants of the reenactment and stimulates a dialogue between memory (both personal and collective/social) and an historical (f)act.

Cumulatively, the 'facts' of the original broadcast of The Man with the Flower in his Mouth are part of what Zoe Beloff has called an 'historical storehouse, ${ }^{36}$ a term which invites a perception of (re)use, where the term archive suggests the act of keeping and protecting. However, the 30 lines / 60 seconds reenactment permits the archive to come alive and supersede 'storing and preserving' into 'transmitting' ${ }^{37}$ as what Zielinski calls a 'practice of resistance. ${ }^{38}$ The project has attempted to go 'under the hood' ${ }^{39}$ of the discarded media object of Baird's first broadcast, as proposed by Huhtamo and Parrika, to speak of the present and the future while uttering the past. The media archaeological process of re-examining the 'evidence' in the present is a potentially creative personal and collective cognitive act.

36 In Jussi Parikka, What is Media Archaeology?, Polity Press, 2012, p. 52.

37 Wolfgang Ernst, Digital Memory and the Archive, University of Minnesota Press, 2013, p. 15.

38 In Erkki Huhtamo and Jussi Parikka, eds, 'Introduction: An Archaeology of Media Archaeology' in Media Archaeologies: Approaches, Applications and Implications, University of California Press, 2011, p. 10.

39 Jussi Parikka, What is Media Archaeology?, Polity Press, 2012, p. 83. 


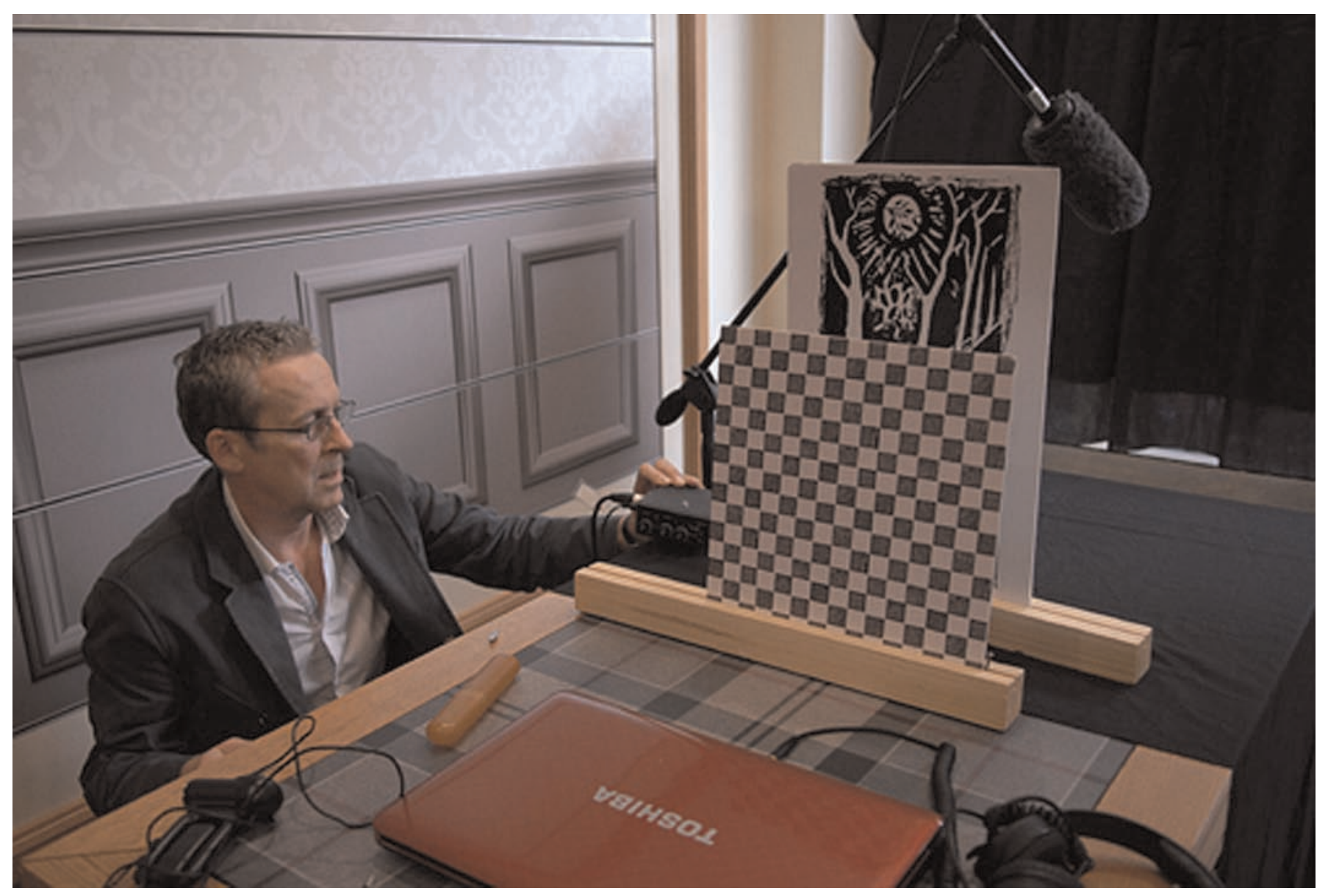

Fig. 18 The author setting up the equipment for 30 lines / 60 seconds at 133 Long Acre, London, September 2014. Image by the author.

Robert Blackson's quote that opens this article is worth revisiting as it claims that reenactment has powers of transformation when memory/history meet theory (in my case, the ramifications of media archaeology, reenactment itself, trace, performance and participation arts practice), and I will leave the viewer and reader to determine whether the results are unique and resonating. ${ }^{40}$

In 30 lines /60 seconds I emulated Baird's 30-line system in the approximate site of his original broadcast, using signifying props, but these are really just fragments and traces that have been picked up "from the roadside" ${ }^{41}$ and gathered together to be re-presented through the technical processes into performance and participation. The significance of the actual act of reenactment is, as Blackson proposes, the "personal motivation" and "openness to interpretation," 42 which was present for all concerned in the project, hopefully including the reader and viewer as they experience its mediation.

As can be seen from the comments made by the participants in their short interview, from my description of personal artistic process and reflection, and from a reader's own thoughts through experiencing this work and this text, the

40 This work is best viewed on an iPhone 4 using Puffin browser (to work with Flash and correct orientation) in order to see the work at the same size as Baird's original broadcast. Figures 20 and 21 are stills taken during the reenactment of the segmented version and Figures 22 and 23 are stills taken during the live 30 lines / 60 seconds reenactment.

41 Erkki Huhtamo and Jussi Parikka, eds, 'Introduction: An Archaeology of Media Archaeology' in Media Archaeologies: Approaches, Applications and Implications, University of California Press, 2011, p. 3.

42 Robert Blackson, 'Once More ... With Feeling: Reenactment in Contemporary Art and Culture,' Art Journal, 66(1), $2007,30$. 


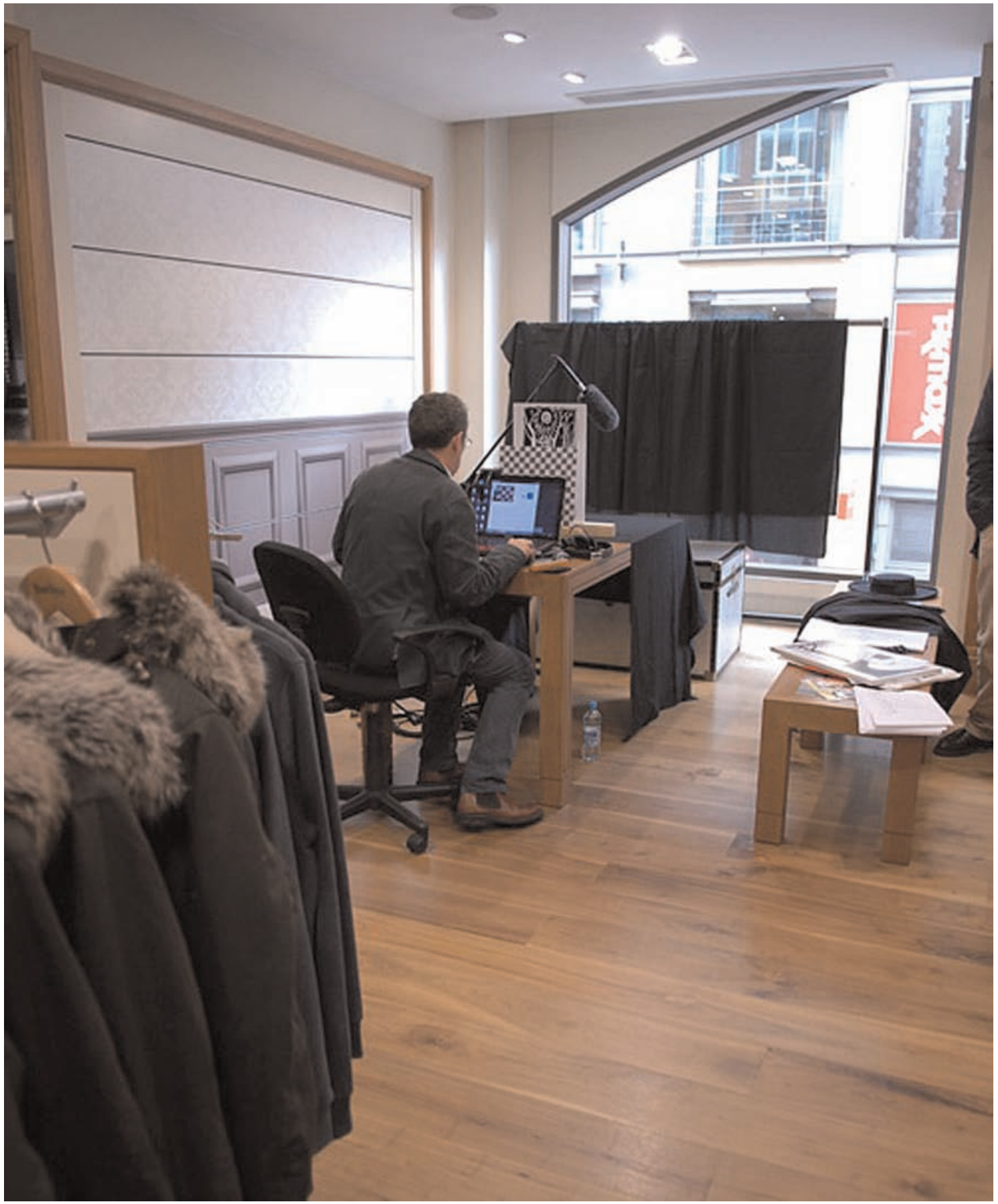

Fig. 19 The author setting up the equipment for 30 lines / 60 seconds at 133 Long Acre, London, in front of the first floor window in Barbour Clothing Store, September 2014. Image by the author.

intention of this project is that of an invitation that is heuristic in nature. The invitation is set against theoretical positions on historical and archival knowledge and its problems, reenactment processes and their potential (both expansive and limitedly mimetic), through a concrete artistic adaptation or realisation of abstract media archaeological invitations. Writing about the ways in which media archaeology might expand into playful experiment, Andreas Fickers suggests that "experimental media archeology tries to explore new ways of experiencing and understanding the materiality of 


\section{VIEU}

P. Ellis, Picking Up (On) Fragments

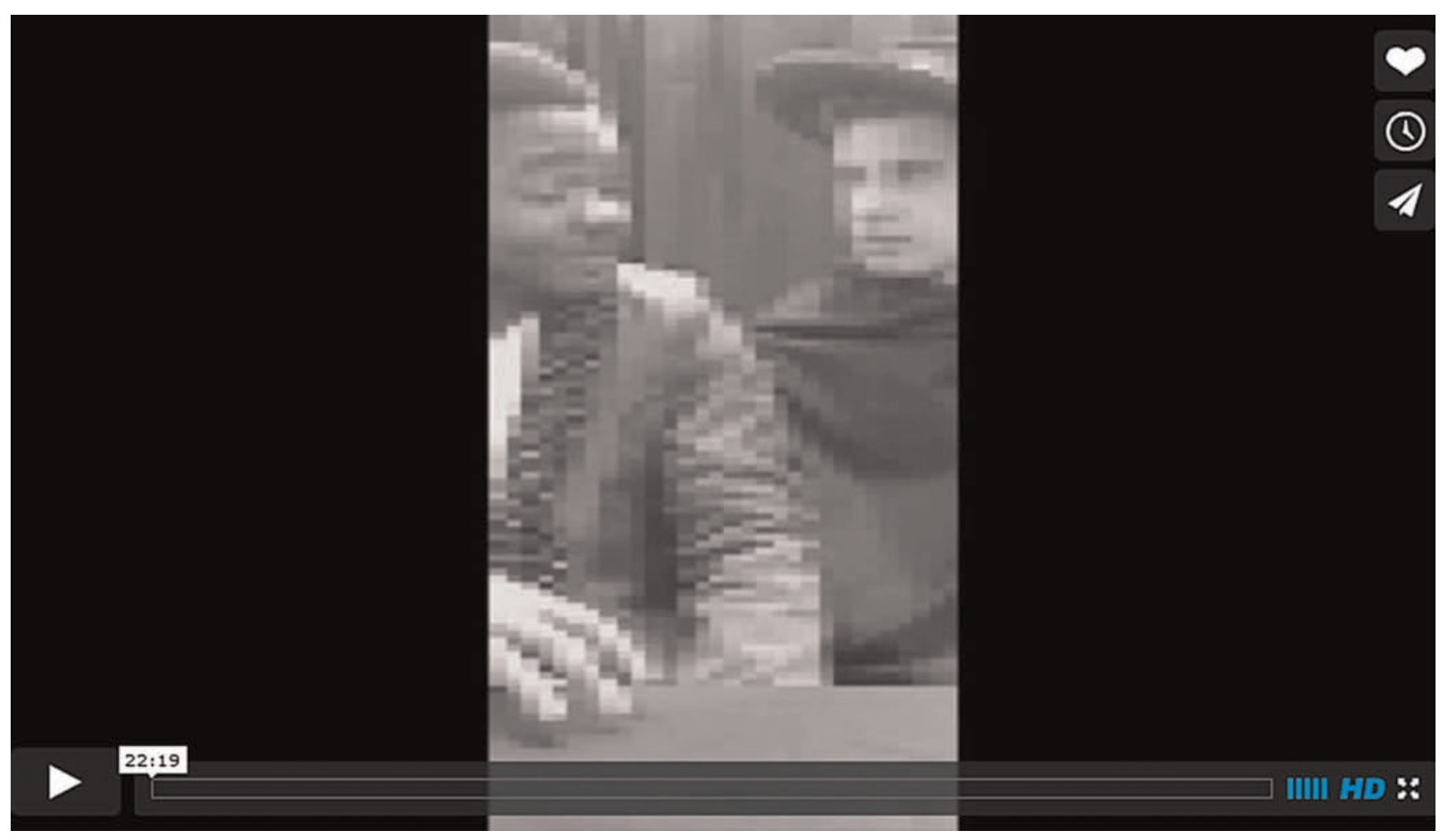

Video 1. The live single take version. Click here to watch it

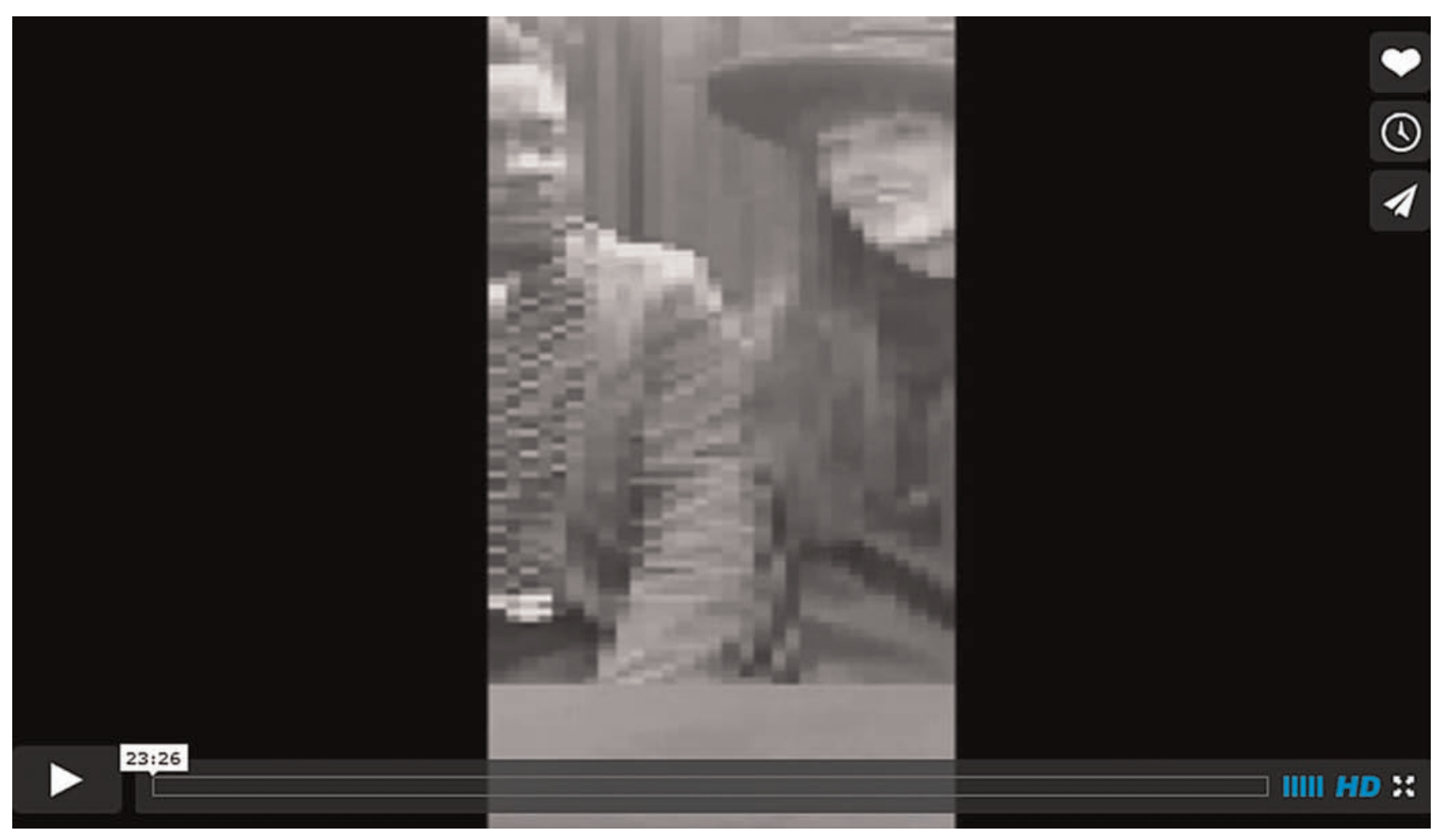

Video 2. The segmented version. Click here to watch it 


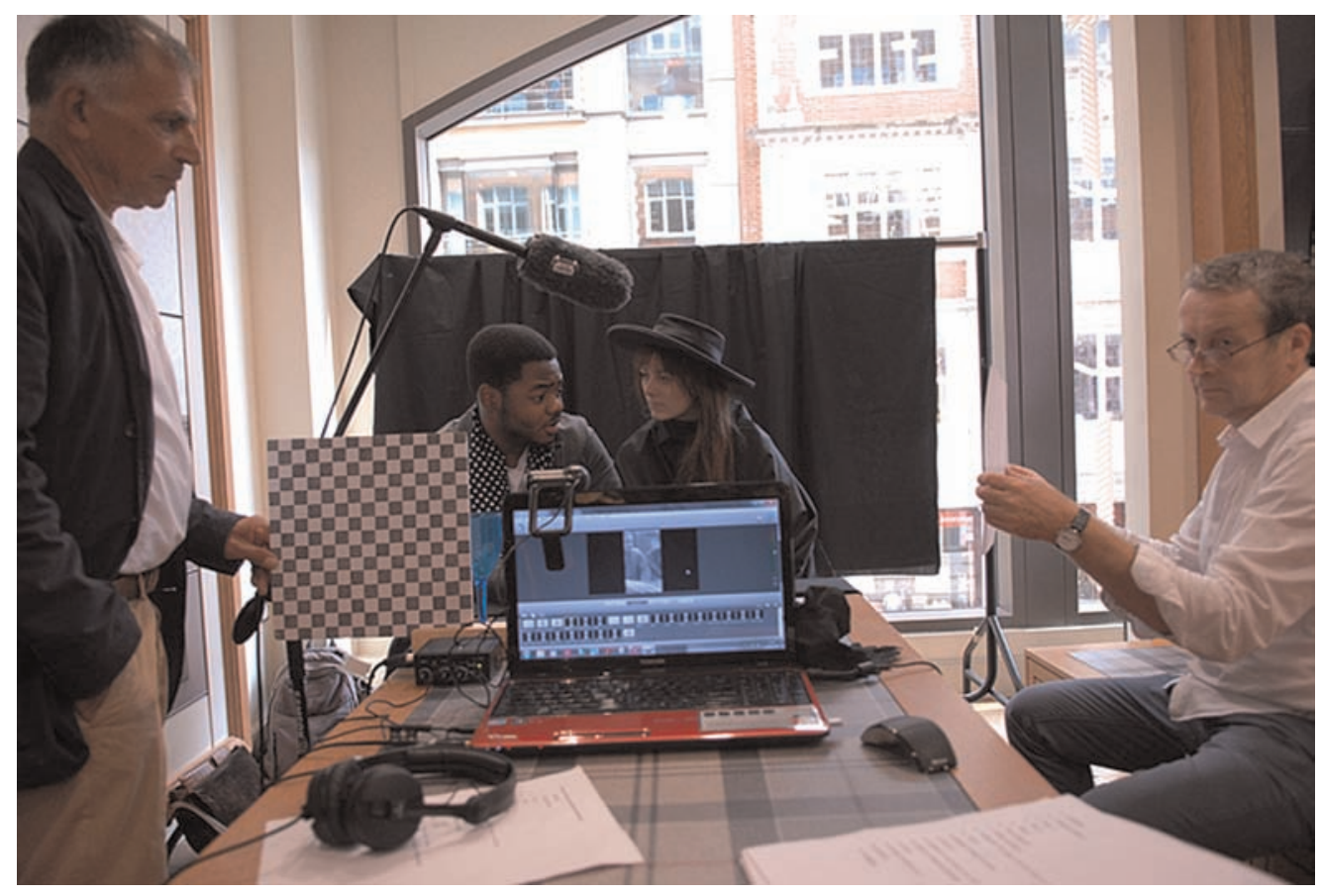

Fig. 20 Still image of the segmented version of 30 lines / 60 seconds at 133 Long Acre, London, September 2014. Image by the author.

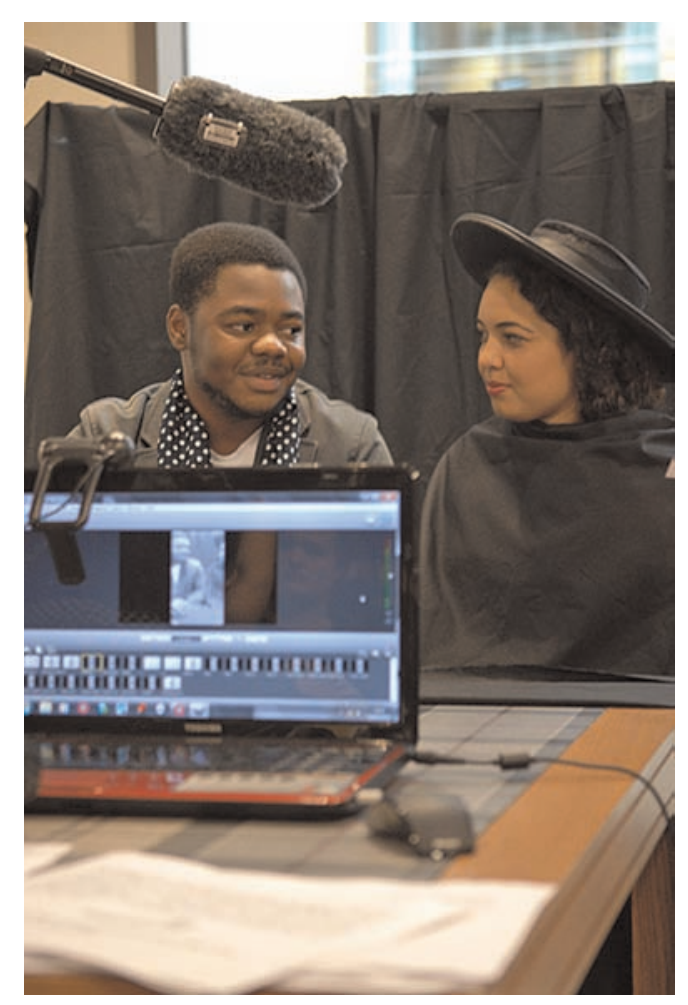

Fig. 21 Still image of the segmented version of 30 lines / 60 seconds at 133 Long Acre, London, September 2014, showing a close up of the 30 line image streamed through Wirecast. Image by the author. 


\section{VIEU}

P. Ellis, Picking Up (On) Fragments

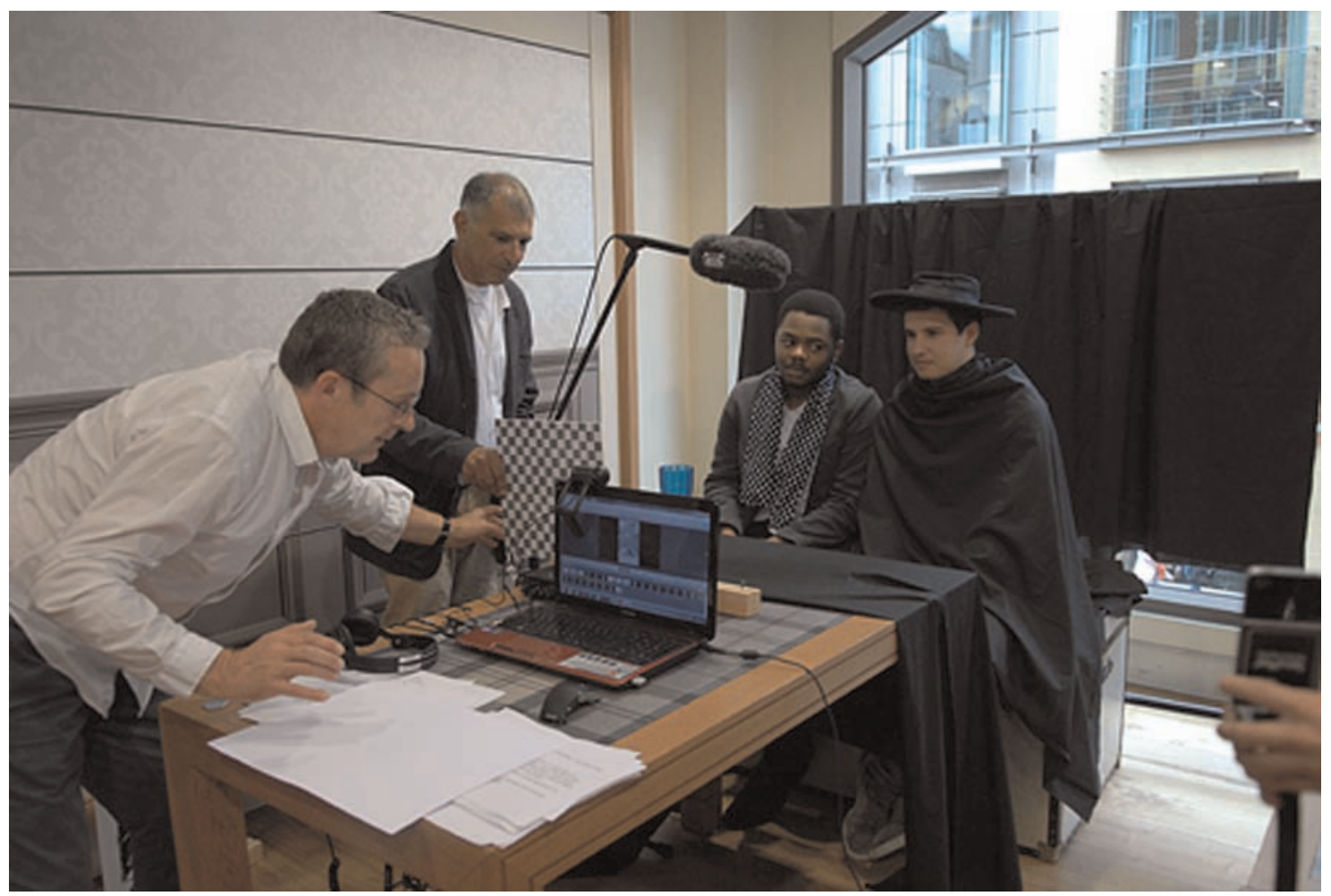

Fig. 22 Still image of the live version of 30 lines / 60 seconds at 133 Long Acre, London, September 2014. Image by the author.

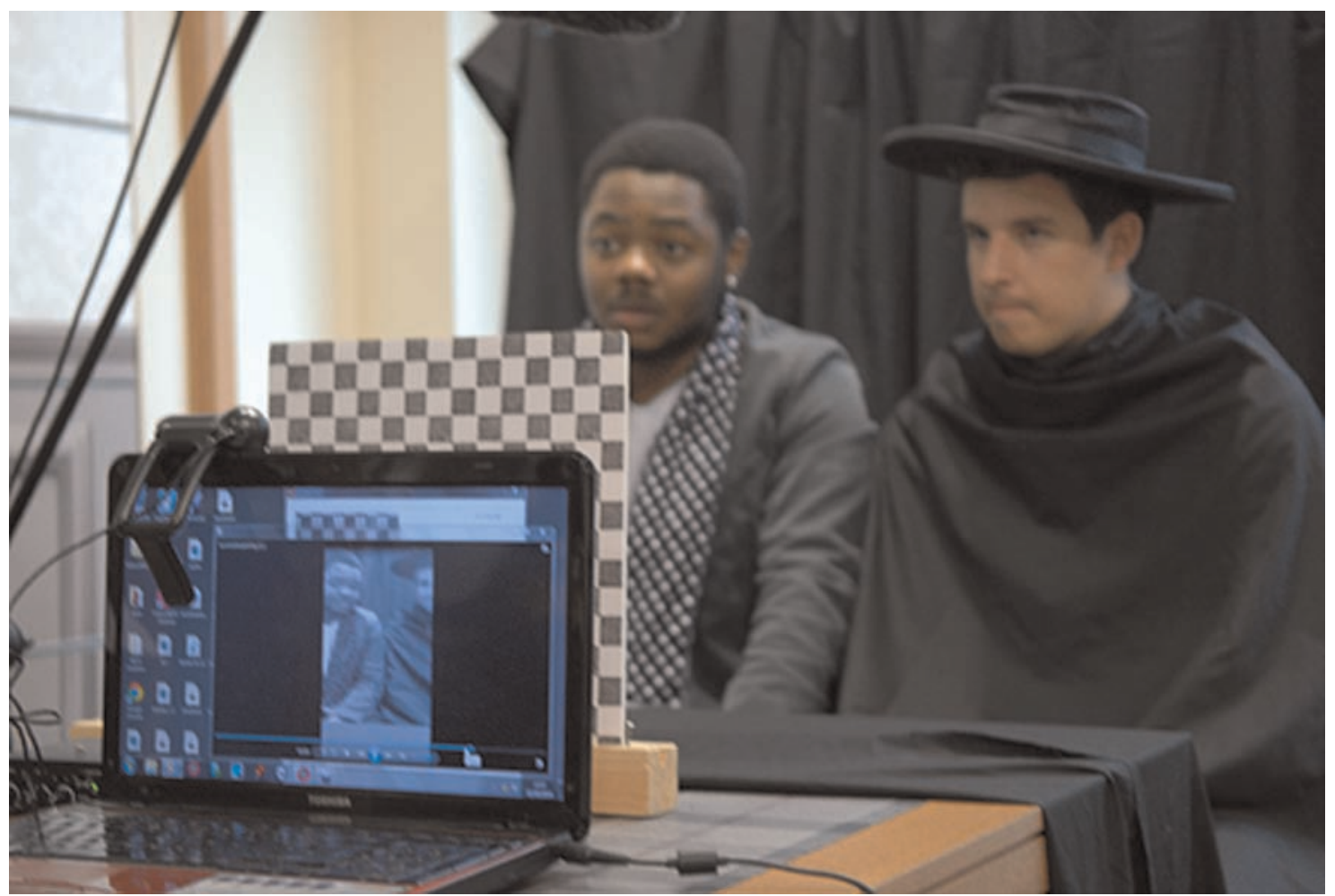

Fig. 23 Still image of the live version of 30 lines / 60 seconds at 133 Long Acre, London, September 2014, showing a close up of the 30 line image streamed through Wirecast. Image by the author. 
media tech-nologies by interacting with these objects in a playful manner". ${ }^{43}$ This project is such a kind of playful experiment that pushes media archaeological research beyond the confines of discourse analysis.

\section{B i o graphy}

Phil Ellis is a digital artist, Associate Head of School-Media Arts and Programme Leader in BA Television Arts at Plymouth University. He is also engaged in $\mathrm{PhD}$ research exploring the relationship between contemporary and historical television, researching into early television experiments and interrogating the relationship between this early technology (and its production process) and our high definition participatory culture through reenactment and performance. His performance work and research take a media archaeological approach seeking traces through this process of reenactment.

Phil recently performed REENACTTV: 30 LINES / 60 SECONDS which was a participatory reenactment of John Logie Baird's 1930 collaboration with the BBC to produce the UK's first TV drama, specifically the broadcast of a version of Luigi Pirandello's The Man with the Flower in his Mouth. The work was performed live at the site of Baird's studio at 133 Long Acre in Septemeber 2014 and during the Opening Night of the HERA: 'Technology, Exchange and Flow: Artistic Media Practices and Commercial Application' at the Kunsthalle, Vienna on March 3rd 2013 and exhibited from March 4-9 2013 and at the Dutch National TV Archives in Hilversum on April 1-19, 2013.

43 Andreas Fickers, 'Hand-On! Plea for an Experimental Media Archaeology,' in Annie van den Oever, ed., Techne/Technology: Researching Cinema and Media Technologies - Their Development, Use, and Impact, Amsterdam University Press, 2013, pp. 272-278. 